SURFACE WATER-QUALITY CHARACTERISTICS IN THE

UPPER NORTH FORK GUNNISON RIVER BASIN, COLORADO

By J. Michael Norris

U.S. GEOLOGICAL SURVEY

Water-Resources Investigations Report 86-4152 


\section{DEPARTMENT OF THE INTERIOR \\ DONALD PAUL HODEL, Secretary \\ U.S. GEOLOGICAL SURVEY}

Dallas L. Peck, Director

For additional information write to:

District Chief U.S. Geological Survey Water Resources Division Box 25046, Mail Stop 415 Federal Center Denver, CO 80225
Copies of this report can be purchased from:

U.S. Geological Survey Books and Open-File Reports Section Federal Center

Box 25425

Denver, CO 80225 
Abstract--

Introduction--

Description of the upper North Fork Gunnison River basin study area----- 2

Data collection--

Water-quality sampling sites-_-

Water-quality data collected-- 5

Water-quality characteristics--

Dissolved solids and specific conductance-(

Major dissolved constituents-

Suspended sediment and trace elements-

Effects of Paonia Reservoir

Effects of coal mining

Hubbard Creek-_..- 36

North Fork Gunnison River- 37

Summary and conclusions-

References-

FIGURES

Figures 1-3. Maps showing:

1. Location of upper North Fork Gunnison River study area-- 3

2. Location of water-quality sampling sites-_..... 4

3. Location of subareas- 8

4-12. Graphs showing:

4. Relation between streamflow and dissolved-solids concentration by subarea-- 10

5. Relation between specific conductance and dissolved solids by subarea-- 13

6. Relation between specific conductance and calcium concentration by subarea-- 16

7. Relation between specific conductance and magnesium concentration by subarea--- 19

8. Relation between specific conductance and sodium concentration by subarea-- 20

9. Relation between specific conductance and alkalinity by subarea-n

10. Relation between streamflow and dissolved-solids concentration for upper and lower Hubbard Creek near Bowie---.-

11. Frequency of occurrence of sulfate concentrations for upper and lower Hubbard Creek, upstream and downstream from coal-mining activities--.--

12. Frequency of occurrence of sulfate concentrations for sites on the North Fork Gunnison River, upstream and downstream from coal-mining

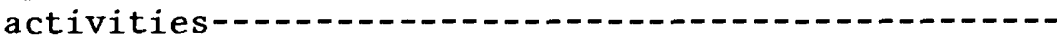


Table 1. Water-quality sampling sites-age

2. Water-quality constituents sampled-_- 7

3. Regression equations to predict dissolved-solids concentration from streamflow-_. 9

4. Dissolved-solids concentration statistics by subarea-------- 11

5. Specific-conductance statistics by subarea--- 14

6. Calcium concentration statistics by subarea----

7. Magnesium concentration statistics by subarea---_- 17

8. Sodium concentration statistics by subarea--

9. Alkalinity concentration statistics by subarea--

10. Potassium concentration statistics by subarea-_-_._.-. 24

11. Chloride concentration statistics by subarea-_... 25

12. Silica concentration statistics by subarea----

13. Sulfate concentration statistics by subarea--

14. Suspended-sediment concentration statistics by subarea-------- 28

15. Total-iron concentration statistics by subarea-- 29

16. Total-manganese concentration statistics by subarea-1-_-_- 31

17. Total-zinc concentration statistics by subarea--

18. Total-lead concentration statistics by subarea-- 33

19. Total-cadmium concentration statistics by subarea---- 34

20. Effects of Paonia Reservoir on water quality of Muddy Creek---- 35

\section{METRIC CONVERSION FACTORS}

\section{Multiply}

acre-foot (acre-ft)

cubic foot per second

$\left(f t^{3} / \mathrm{s}\right)$

foot (ft)

inch per year (in/yr)

mile (mi)

square mile $\left(\mathrm{mi}^{2}\right)$

ton (short)

ton per day (ton/d)
By

0.001233

0.02832

0.3048

2.54

1.69

2.590

907.2

907.2

\section{To obtain}

cubic hectometer

cubic meter per second

$$
\left(\mathrm{m}^{3} / \mathrm{s}\right)
$$

$$
\text { meter }
$$

centimeter per year

kilometer $(\mathrm{km})$

square kilometer $\left(\mathrm{km}^{2}\right)$

kilogram

kilogram per day

Degree Fahrenheit $\left({ }^{\circ} \mathrm{F}\right)$ may be converted to degree Celsius $\left({ }^{\circ} \mathrm{C}\right)$ by using the following equation:

$$
{ }^{\circ} \mathrm{C}=5 / 9\left({ }^{\circ} \mathrm{F}-32\right)
$$

The following terms and abbreviations also are used in this report:

milligrams per liter $(\mathrm{mg} / \mathrm{L})$

micrograms per liter $(\mu \mathrm{g} / \mathrm{L})$

microsiemens per centimeter $(\mu \mathrm{S} / \mathrm{cm})$

Sea level: In this report "sea level" refers to the National Geodetic Vertical Datum of 1929 (NGVD of 1929)--a geodetic datum derived from a general adjustment of the first-order level nets of both the United States and Canada, formerly called "Mean Sea Level of 1929." 


\title{
SURFACE WATER-QUALITY CHARACTERISTICS IN THE UPPER \\ NORTH FORK GUNNISON RIVER BASIN, COLORADO
}

By J. Michael Norris

\begin{abstract}
Analyses of water-quality data collected during 1982 and 1983 in the upper North Fork Gunnison River basin indicate that dissolved-solids concentrations are relatively small, with a mean value near 97 milligrams per liter. Most major dissolved constituents also had small measured concentrations throughout the study area. Trace-element concentrations generally were sma11; however, total-iron concentration generally was large in the area with a mean concentration of about 8,250 micrograms per liter. The cause of this larger iron concentration probably is related to the local geology.

Paonia Reservoir, located on Muddy Creek, greatly reduced suspendedsediment and trace-element concentrations. The reservoir had only a slight effect on major dissolved-constituent concentrations.

Analyses of alkalinity, sulfate, and dissolved-solids concentrations indicated that little, if any, changes in water quality occur as a result of coal mining; however, more data are needed to make more definite conclusions. Sulfate concentrations increased slightly downstream through the mined area; however, with the small concentrations measured and limited quantity of data, the source of the increased sulfate could not be determined.
\end{abstract}

\section{INTRODUCTION}

Mining of coal in the upper North Fork Gunnison River basin started in 1903 and continues to the present (1984). To determine the effect coal mining might have on water resources, the background, or natural, water-quality conditions must be known. However, in the upper North Fork Gunnison River basin, as in many other coal-mining areas, little hydrologic data are available to describe either natural conditions or any effects from man's activities.

The objective of this report is to describe the water-quality characteristics of the North Fork Gunnison River basin upstream from Paonia. This report also presents water-quality information from specific sampling sites, upstream and downstream from coal mining, to evaluate the effect coal mining might have on the area's water quality. 


\section{DESCRIPTION OF THE UPPER NORTH FORK GUNNISON RIVER BASIN STUDY AREA}

The study area is located in western Colorado in parts of Delta and Gunnison Counties that include the North Fork of the Gunnison River drainage basin upstream from Paonia (fig. 1). Generally, the $653 \mathrm{mi}^{2}$ drainage area is characterized by steep slopes. However, rolling hills are found at lower elevations. The elevation ranges from 13,058 on Mount Owens to 5,608 ft on the North Fork of the Gunnison River in the study area outlet near Paonia.

Climate and vegetation are strongly influenced by elevation and vary throughout the study area. Climate is semiarid at lower elevations and alpine at higher elevations. Precipitation averages about $25 \mathrm{in} / \mathrm{yr}$ over the basin, with most precipitation, especially at higher elevations, in the form of snow. Air temperature in the area varies from below zero in the winter to over $90^{\circ} \mathrm{F}$ in the summer.

Vegetation at lower elevations consists of grasses and shrubs, with deciduous trees along stream channels. Major vegetation at higher elevations are evergreen forests, with the dominant trees being pine, spruce, fir, and aspen.

Major geologic formations in the area are the Tertiary Wasatch Formation and underlying Cretaceous Mesaverde Formation, including the Ohio Creek Member at the top. These sedimentary formations contain claystone, siltstone, sandstone, conglomerate, and shale. Other geologic units in the area include the Cretaceous Mancos Shale, underlying the Mesaverde, middle Tertiary intrusive rocks, and numerous landslide deposits (Tweto and others, 1976, 1978).

Underground coal mining started in the basin in 1903 and by 1982 production totaled $39,850,000$ short tons, with 2,649,400 short tons mined in 1982 (Rushworth and others, 1984). Coal in the study area is in the Somerset coal field and is bituminous. Rushworth and others (1984) estimated that coal reserves in 1982 were $3,348,000,000$ short tons.

Paonia Reservoir is the major hydrologic feature in the study area. The dam was built in 1962 by the U.S. Bureau of Reclamation. Paonia Reservoir dam is located on Muddy Creek approximately one-half mile upstream from the confluence of Muddy Creek and Anthracite Creek, where they form the North Fork Gunnison River. The dam has a structural height of $177 \mathrm{ft}$. The reservoir has a maximum capacity of 23,230 acre-ft, and a normal capacity of 20,950 acre-ft. The major uses of the reservoir's water are irrigation, recreation, water supply, and flood control.

\section{DATA COLLECTION}

Four continuous streamflow-gaging stations currently (1984) are in operation in the study area and are shown in figure 2. One of the gaging stations is a U.S. Geological Survey station and the other three stations are operated by the State of Colorado. The U.S. Geological Survey station, North Fork Gunnison River near Somerset (fig. 2, site 4) has streamflow records from 


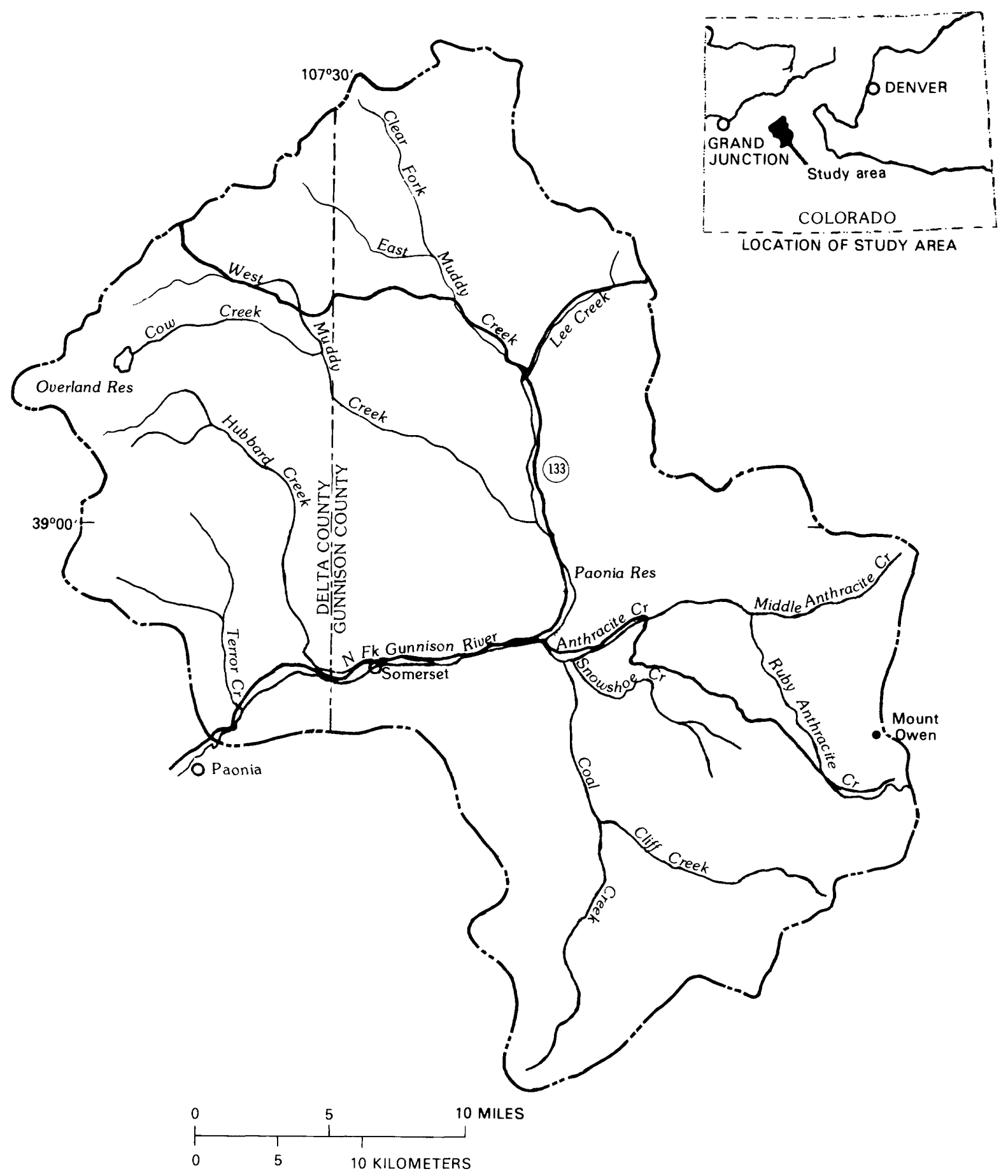

Figure 1.--Location of upper North Fork Gunnison River study area. 


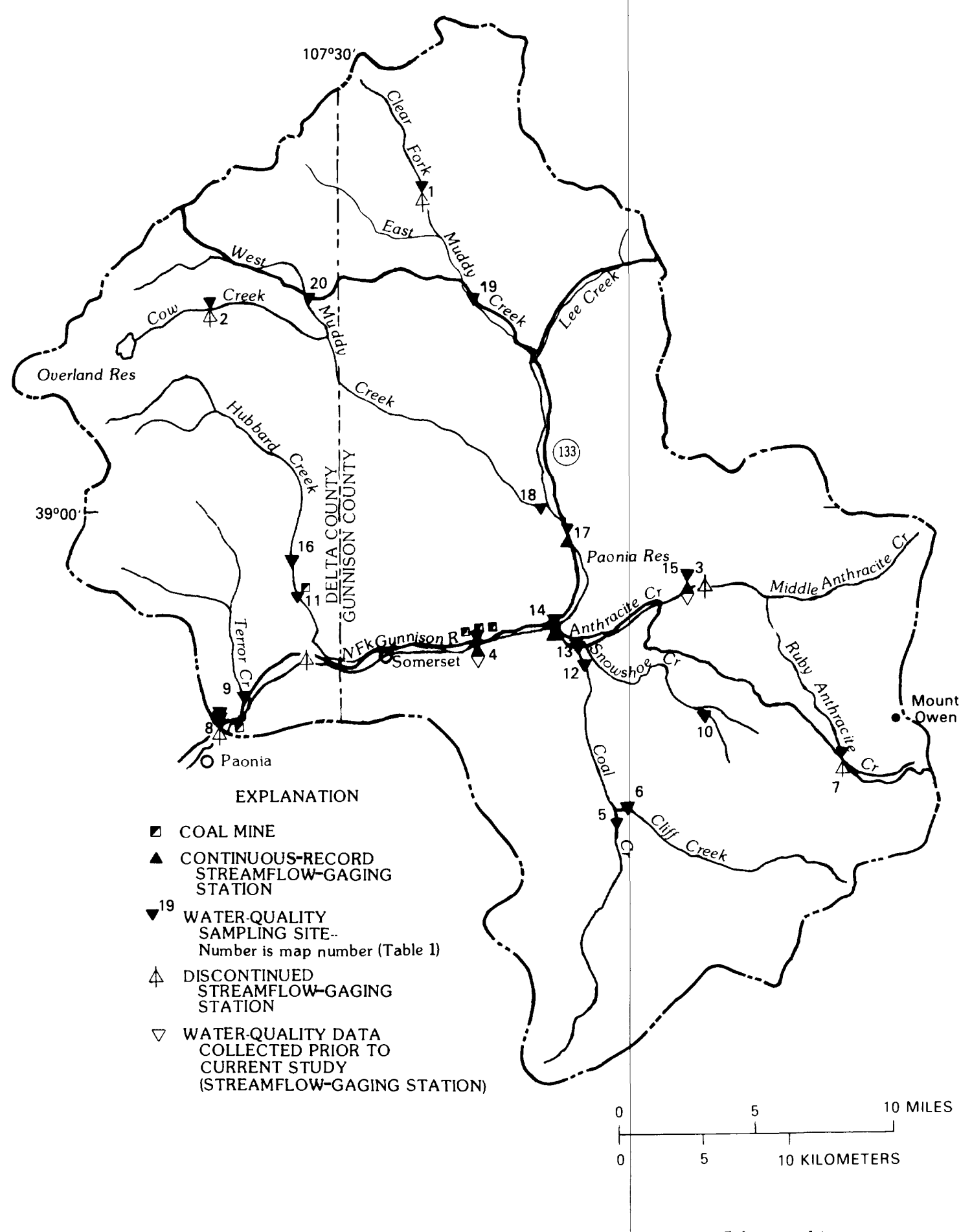

Figure 2.--Location of water-quality sampling sites. 
1934 to the present (1984), and water-quality data have been collected periodically. The three State-operated streamflow-gaging stations, upper Anthracite Creek near Somerset (fig. 2, site 15), Muddy Creek below Paonia Reservoir (fig. 2, site 14), and Muddy Creek above Paonia Reservoir (fig. 2, site 17), only have streamflow data. However, a discontinued U.S. Geological Survey streamflow-gaging station, Anthracite Creek near Somerset (fig. 2, site 3) has streamflow and water-quality data from 1977 to 1981, at a point approximately one-half mile upstream from the State-operated Anthracite Creek streamflow-gaging station. Other U.S. Geological Survey discontinued streamflow-gaging stations in the area include Clear Fork near Ragged Mountain (fig. 2, site 1), that operated from 1965 to 1973, Cow Creek near Paonia (fig. 2, site 2), that operated from 1969 to 1982, and Ruby Anthracite Creek near Kebler Pass (fig. 2, site 7).

\section{Water-Quality Sampling Sites}

Nineteen water-quality sampling sites were established in the area for this study (fig. 2). The location and drainage area are listed in table 1. One site shown in figure 2 and in table 1, Anthracite Creek near Somerset (fig. 2, site 3), was not used as a water-quality sampling site for this study, but the data from this site are included in the analyses in this report because both streamflow and water-quality data are available from 1977 to 1981 .

The water-quality sampling sites were selected to account for variations in geology, vegetation, elevation, and land use. Because of high elevations in parts of the area, accessibility also was considered in site location. In early spring some areas at higher elevations are inaccessible because of snow depth.

\section{Water-Quality Data Collected}

Water-quality data were collected synoptically starting in the spring of 1982 through the fall of 1983. Water-quality constituents measured are listed in table 2. All major constituents in this report were analyzed for the dissolved concentrations and the trace elements were analyzed for the total concentrations. Samples were collected throughout the range of flows to determine the variability of the water quality during different seasons and for different flow conditions. Samples for water-quality analyses were collected by standard procedures (Brown and others, 1970), and analyzed by the U.S. Geological Survey Laboratory in Denver, using established methods (Skougstad and others, 1979). Measurements of streamflow, pH, water temperature, and specific conductance were made at the time of sample collection. Data collected during this study are presented in Norris and Maura (1985).

\section{WATER-QUALITY CHARACTERISTICS}

For water-quality data interpretation, the study area was divided into four subareas (fig. 3), based on differences in geology and elevation. In the following discussion, the geologic formations for the subareas are listed by relative occurrence within each subarea. Geology of the Muddy Creek subarea 


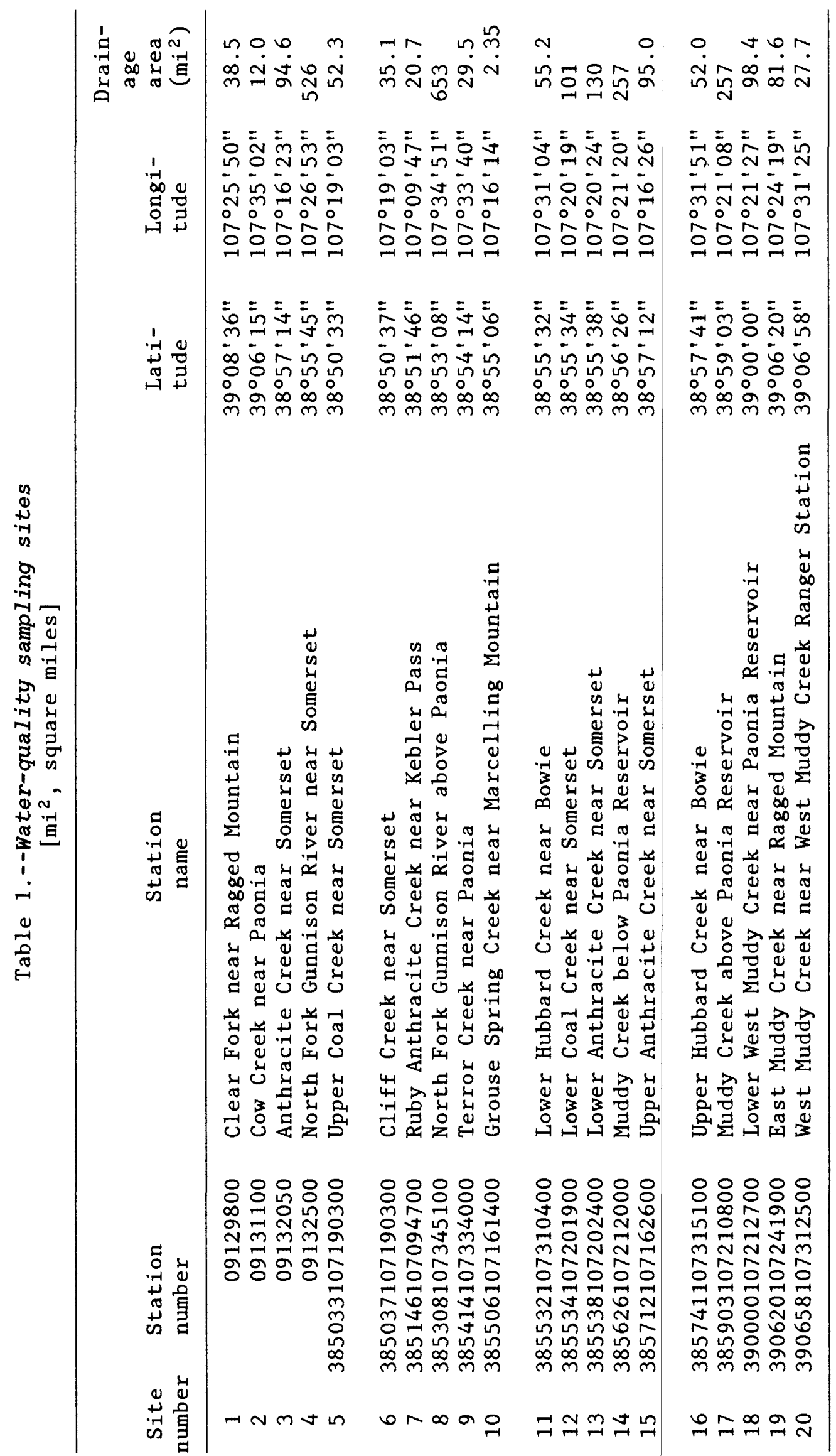


Table 2.--Water-quality constituents sampled ${ }^{1}$

$\begin{array}{cc}\frac{\text { Major constituent }}{\text { (dissolved concentration) }} & \begin{array}{c}\text { Trace elements } \\ \text { (total concentration) }\end{array} \\ \text { Silica } & \text { Aluminum } \\ \text { Nitrogen }\left(\mathrm{NO}_{2}+\mathrm{NO}_{3}\right) & \text { Arsenic } \\ \text { Chloride } & \text { Cadmium } \\ \text { Fluoride } & \text { Chromium } \\ \text { Sulfate } & \text { Cobalt } \\ \text { Calcium } & \text { Copper } \\ \text { Magnesium } & \text { Iron } \\ \text { Potassium } & \text { Lead } \\ \text { Sodium } & \text { Manganese } \\ \text { Alkalinity }\left(\mathrm{CaCO}_{3}\right) & \text { Mercury } \\ & \text { Selenium } \\ & \text { Zinc }\end{array}$

${ }^{1} \mathrm{pH}$, water-temperature, specific-conductance, and suspended-sediment data were also collected.

consists mainly of the Wasatch Formation and Ohio Creek Member at the top of the Mesaverde Formation, with some young glacial drift and landslide deposits. Geology of the Anthracite Creek subarea is more complex, consisting of young glacial drift, the Wasatch Formation, Mesaverde Group undivided, or Mesaverde Formation, including the Ohio Creek Member at the top, some Mancos Shale, and middle Tertiary intrusive rocks. This subarea also has the highest average elevation of all subareas. Geology of the Hubbard and Terror Creeks subarea consists of landslide deposits, Wasatch Formation, and the upper part of the Mesaverde Formation, including the Ohio Creek member at the top, and Mancos Shale. The Hubbard and Terror Creeks subarea also has a lower average elevation than the Muddy Creek and Anthracite Creek subareas. The North Fork Gunnison River subarea primarily represents the mainstem of that river and was delineated as a subarea to compare the water quality of the North Fork Gunnison River to the other subareas. The geology of this subarea consists mostly of alluvial deposits.

To test the validity of subdividing the area, a statistical analysis of the average concentrations for each major dissolved and trace element constituent from the 19 stations was completed. Using the Duncan's multiplerange test, results showed that, generally, the stations were grouped into the four major subareas shown in figure 3 , and the four subareas had statistically different water-quality characteristics, significant at the 95-percent level. 


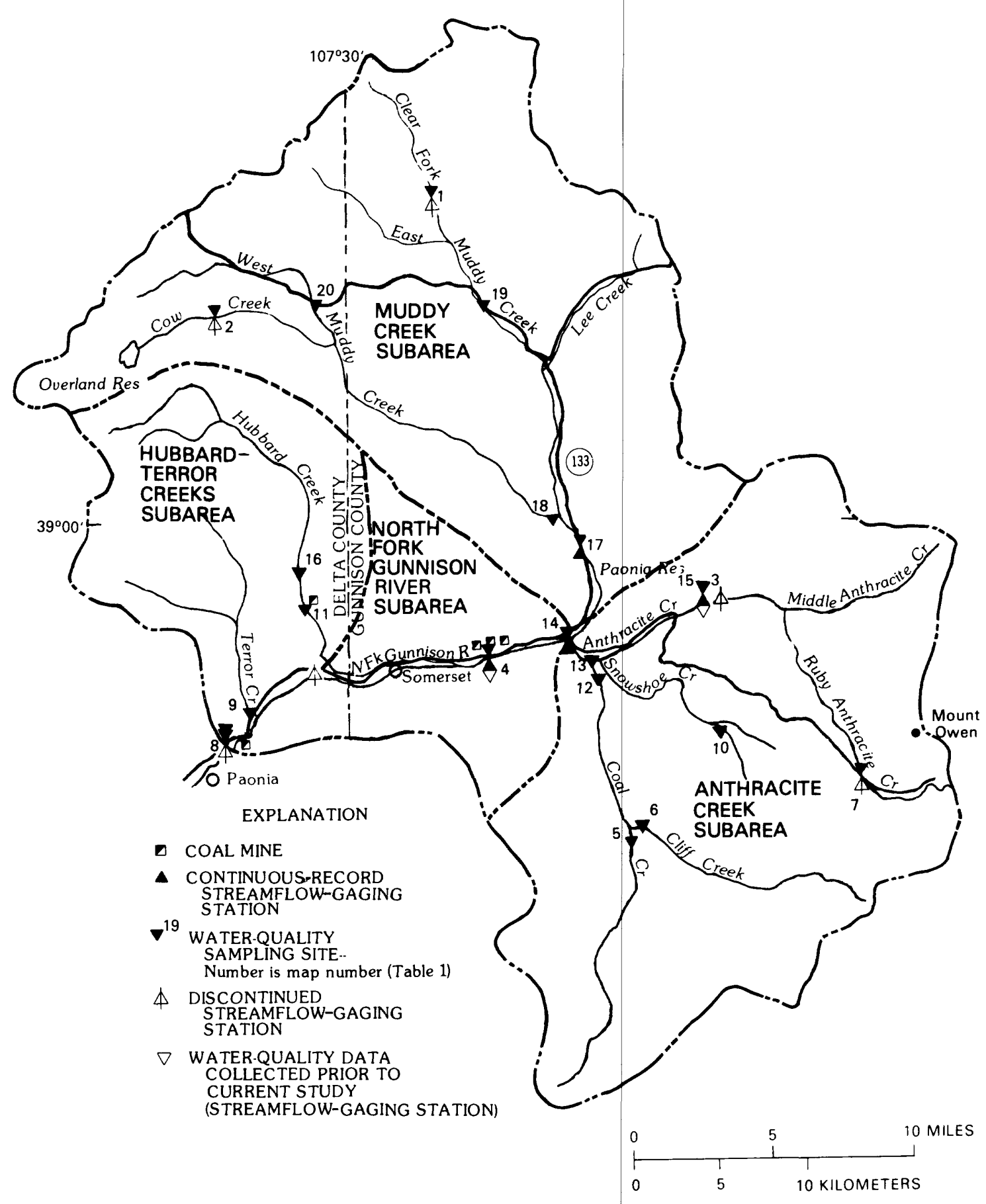

Figure 3.--Location of subareas. 


\section{Dissolved Solids and Specific Conductance}

Dissolved solids is the total concentration of dissolved material in water (Hem, 1970). Dissolved-solids concentrations often are used to describe general water quality and compare the water quality of different areas. At many sites, relations between streamflow and dissolved-solids concentrations can be developed for estimating dissolved-solids concentration from streamflow. Relations of this type for the four subareas and the entire study area are presented in table 3 . As demonstrated by the correlation coefficients ( $r$-values) in table 3, only the Hubbard and Terror Creeks subarea, and possibly the North Fork Gunnison River subarea, have a relation that adequately provides a dissolved-solids concentration estimate from streamflow.

Table 3.--Regression equations to predict dissolved-solids concentration from streamflow

[p, probability of obtaining a larger value of $r$ with $n$ pairs of randomly related data]

\begin{tabular}{|c|c|c|c|c|c|c|}
\hline $\begin{array}{l}\text { Subarea } \\
\text { name }\end{array}$ & $\underset{B}{\text { ponent }^{1}}=$ & $\begin{array}{c}\text { Coeffi- } \\
\text { cient }{ }^{1} \\
\text { A }\end{array}$ & $\begin{array}{l}\text { Corre- } \\
\text { lation } \\
\text { coeffi- } \\
\text { cient } \\
\quad(r)\end{array}$ & $\begin{array}{l}\text { Root } \\
\text { mean } \\
\text { square } \\
\text { error } \\
\text { (percent) }\end{array}$ & $\begin{array}{l}\text { Number } \\
\text { of data } \\
\text { pairs } \\
\text { (n) }\end{array}$ & $\begin{array}{l}\text { Prob- } \\
\text { ability } \\
\text { (p) }\end{array}$ \\
\hline $\begin{array}{l}\text { Muddy Creek } \\
\text { subarea }\end{array}$ & -0.058 & 147 & -0.27 & 40.0 & 77 & 0.0093 \\
\hline $\begin{array}{l}\text { Anthracite Creek } \\
\text { subarea } \\
\text { Hubbard and Terror }\end{array}$ & -.057 & 71.1 & -.37 & 21.8 & 54 & .0031 \\
\hline $\begin{array}{l}\text { Creeks subarea } \\
\text { North Fork Gunnison }\end{array}$ & -.162 & 196 & -.85 & 25.2 & 30 & .0001 \\
\hline River subarea & -.117 & 172 & -.64 & 21.6 & 70 & .0001 \\
\hline Total Area & -.109 & 151 & -.49 & 41.5 & 234 & .0001 \\
\hline
\end{tabular}

${ }^{1}$ The equation is: $S=A(Q)^{B}$, where $S=$ dissolved-solids concentration, in milligrams per liter; and $Q=$ streamflow, in cubic feet per second.

Plots of the streamflow dissolved-solids concentration relations in table 3 are shown in figure 4. Two important aspects of the area are demonstrated in figure 4: (1) Water in the Anthracite Creek subarea has a smaller dissolved-solids concentration than water in the other subareas; and (2) Muddy Creek and Anthracite Creek have a direct effect on the water quality of the North Fork Gunnison River. Approximately 91 percent of the mean-annual streamflow measured for the North Fork Gunnison River at the most downstream site (fig. 2, site 8) is contributed by the Muddy Creek and Anthracite Creek subareas. As the mean-annual streamflow from the Anthracite Creek subarea is approximately 50 percent larger than the mean-annual streamflow from the Muddy Creek subarea, the water quality in the North Fork Gunnison River would be 
expected to resemble more closely the water quality from the Anthracite Creek subarea. However, this is not the case as shown in figure 4. At smaller streamflows (larger dissolved-solids concentrations), the value of the dissolved-solids concentration in the North Fork Gunnison River is nearer to the dissolved-solids concentration in the Muddy Creek subarea. In addition, the mean value of the dissolved-solids concentration (table 4) in the North Fork Gunnison River subarea is between the mean value of the dissolved-solids concentration of the Muddy Creek subarea and the mean value of the dissolvedsolids concentration of the Anthracite Creek subarea.

Paonia Reservoir is a probable factor causing the similar dissolved-solids concentration in the North Fork Gunnison River subarea to the dissolved-solids concentration of the Muddy Creek subarea at lesser streamflows. As with most reservoirs, the effects of Paonia Reservoir on streamflow are to decrease peak flows and increase low flows by storing flood flows, and slowly releasing the stored water. Increasing the percentage of streamflow in the North Fork Gunnison River during smaller streamflows from Muddy Creek probably causes the dissolved-solids concentration in the North Fork Gunnison River to be nearer the concentration in Muddy Creek than the concentration in Anthracite Creek during those smaller streamflows. Other effects of Paonia Reservoir are discussed in a later section.

The largest dissolved-solids concentrations in the study area are in the Hubbard and Terror Creeks subarea (table 4). These relatively large concentrations in the Hubbard and Terror Creek subarea are mainly caused by the saline sedimentary formations in the basins. The mean dissolved-solids concentration for the total area is $97 \mathrm{mg} / \mathrm{L}$.

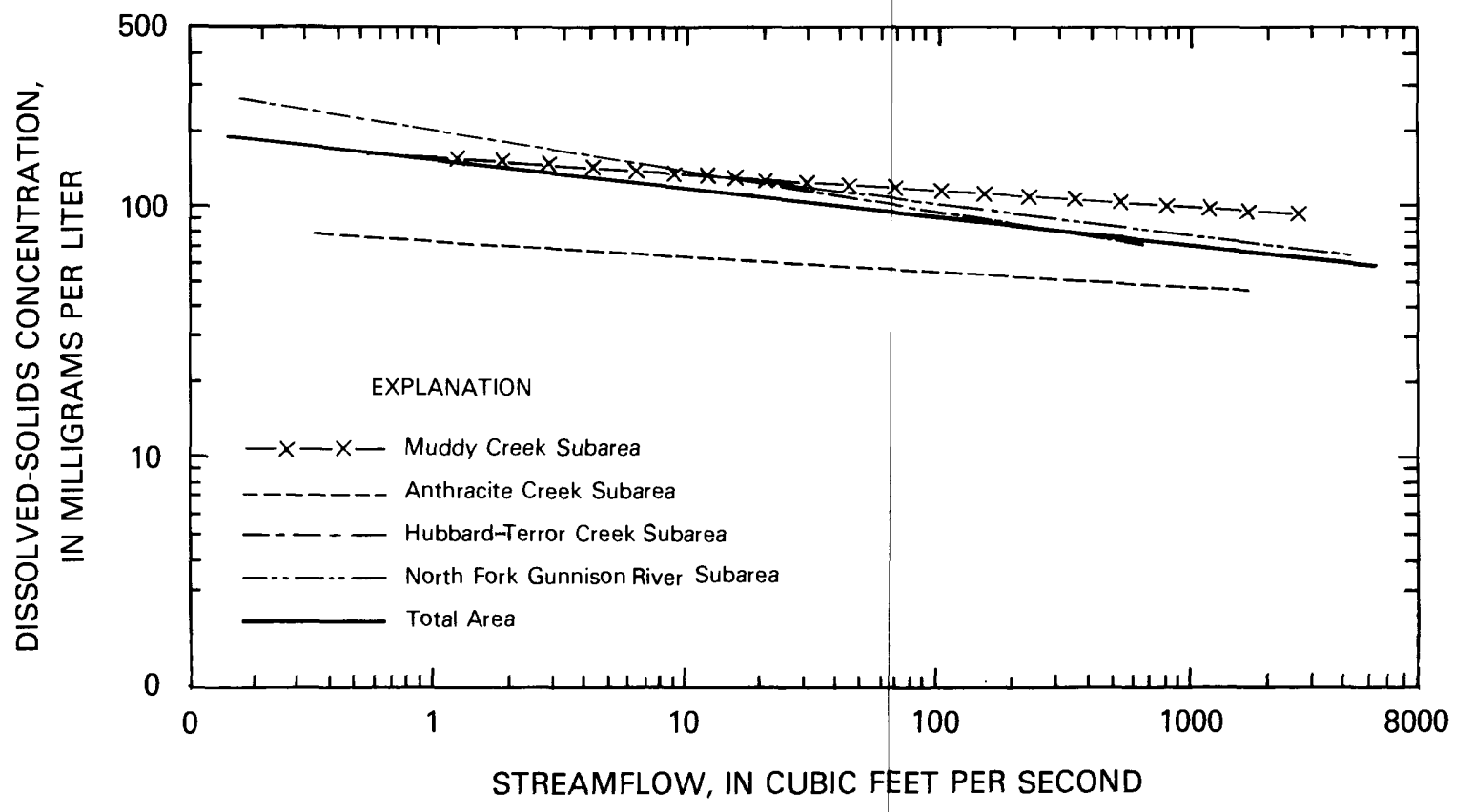

Figure 4.--Relation between streamflow and dissolved-solids concentration by subarea. 


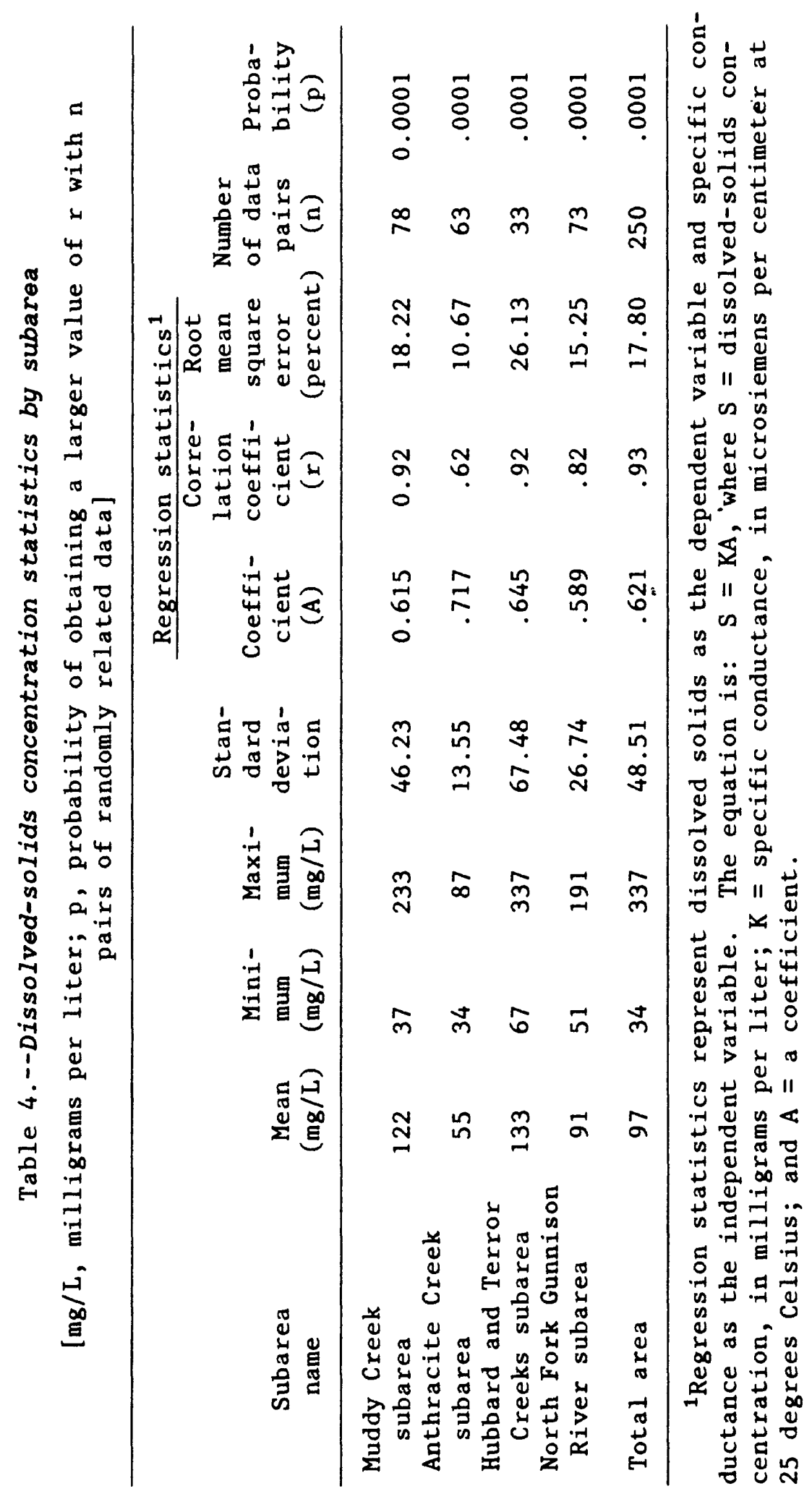


Another method for estimating dissolved-solids concentration is to develop relations between dissolved solids and the specific conductance of the water. Relations of this type for this area are presented in table 4 . Hem (1970) states that the equation for this relation is:

$$
\mathrm{S}=\mathrm{KA} \text {; }
$$

where

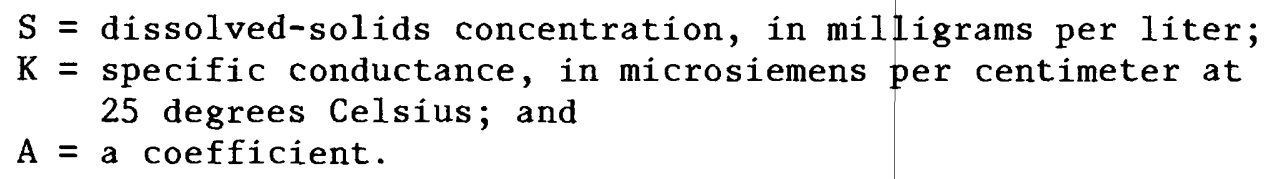

Based on the generally good correlation shown in table 4, the equations appear adequate for estimating dissolved-solids concentration from specific conductance in the study area. These relations are plotted in figure 5 and show similar relations for all subareas. The relatively small values of specific conductance for the Anthracite Creek subarea also are shown in figure 5 .

Specific conductance values for the subareas and for the total area are summarized in table 5 . Values for the statistical relation to estimate specific conductance from streamflow also are presented in table 5 . As with the relations for estimating dissolved solids from streamflow, only the Hubbard and Terror Creeks subarea relation has good correlation $(r=-0.89)$ to indicate an adequate relation for predicting specific conductance from streamflow. The correlation for the North Fork Gunnison River $(r=-0.66)$ suggests that this equation also may be useful for estimating specific conductance from streamflow.

\section{Major Dissolved Constituents}

For each subarea, the mean, minimum, maximum, and standard deviation for dissolved-calcium concentration are shown in table 6 . The mean concentration of dissolved calcium in the North Fork Gunnison River subarea is quite similar to the average of the mean concentrations of the Muddy Creek and Anthracite Creek subareas. Values for the regression equations to predict dissolved calcium concentration from specific conductance also are presented in table 6 for each subarea and for the total area. These equations are plotted in figure 6. The equation for the total area, with an $r$-value of 0.94 , appears to adequately predict dissolved-calcium concentration for any site within the study area, especially at smaller conductance values. However, at larger conductance values, the total area equation would slightly overpredict dissolved-calcium concentration for sites in all subareas except the Muddy Creek subarea, where the equation would underpredict (figure 6).

The mean, minimum, maximum, and standard deviation for dissolvedmagnesium concentrations are presented in table 7 and the same values for sodium are in table 8 . For both constituents, the largest mean concentrations are in the Hubbard and Terror Creeks subarea, and the smallest mean concentrations are in the Anthracite Creek subarea. Regression-equation coefficients to estimate the constituent from specific-conductance values also are in tables 7 and 8 . These equations are plotted in figure 7 for magnesium and in figure 8 for sodium. From table 7 and figure 7 , all subareas have similar prediction equations for magnesium concentration, except for the Hubbard and Terror Creeks subarea, which has larger values and a steeper slope. 


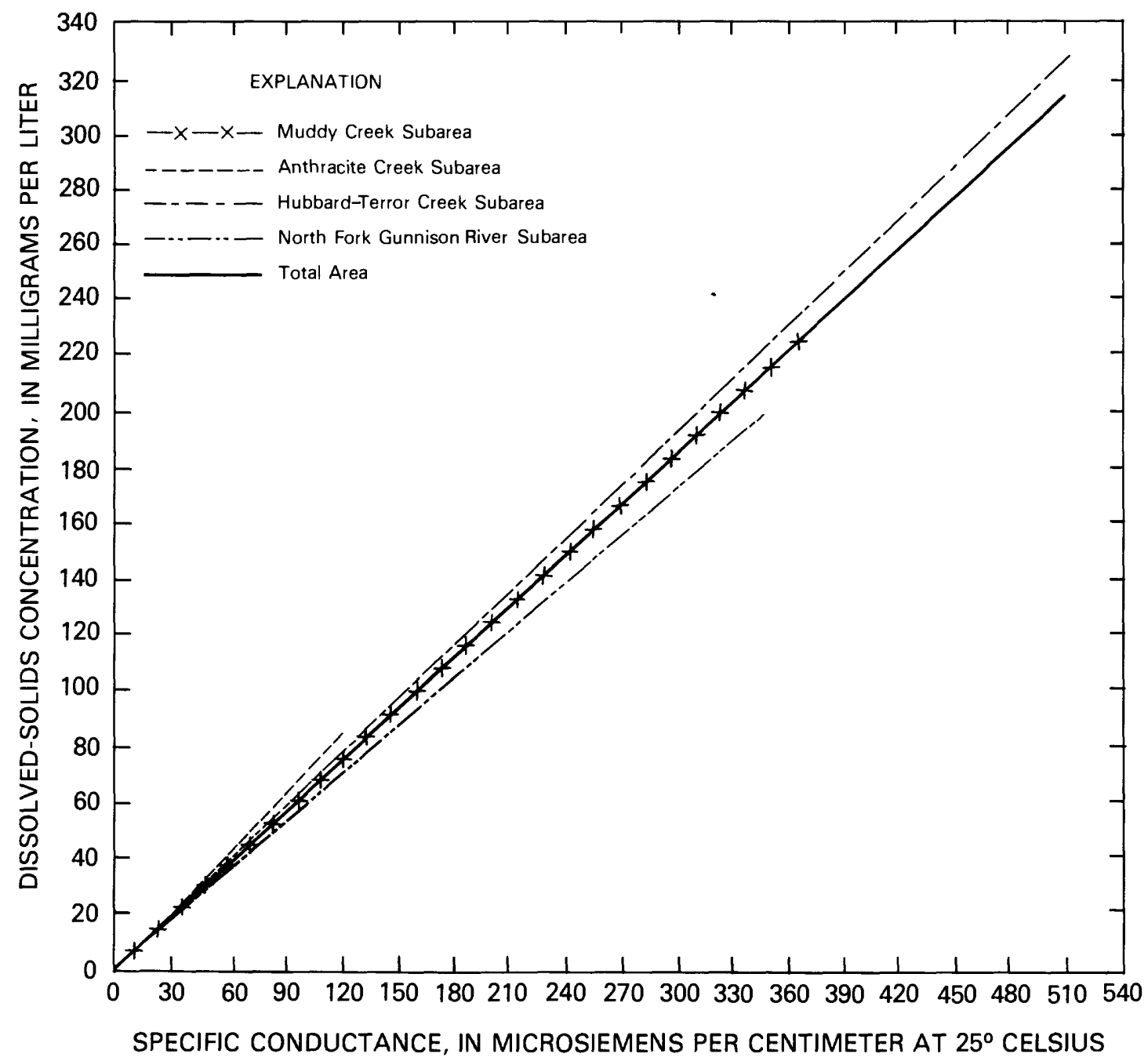

Figure 5.--Relation between specific conductance and dissolved-solids concentration by subarea. 


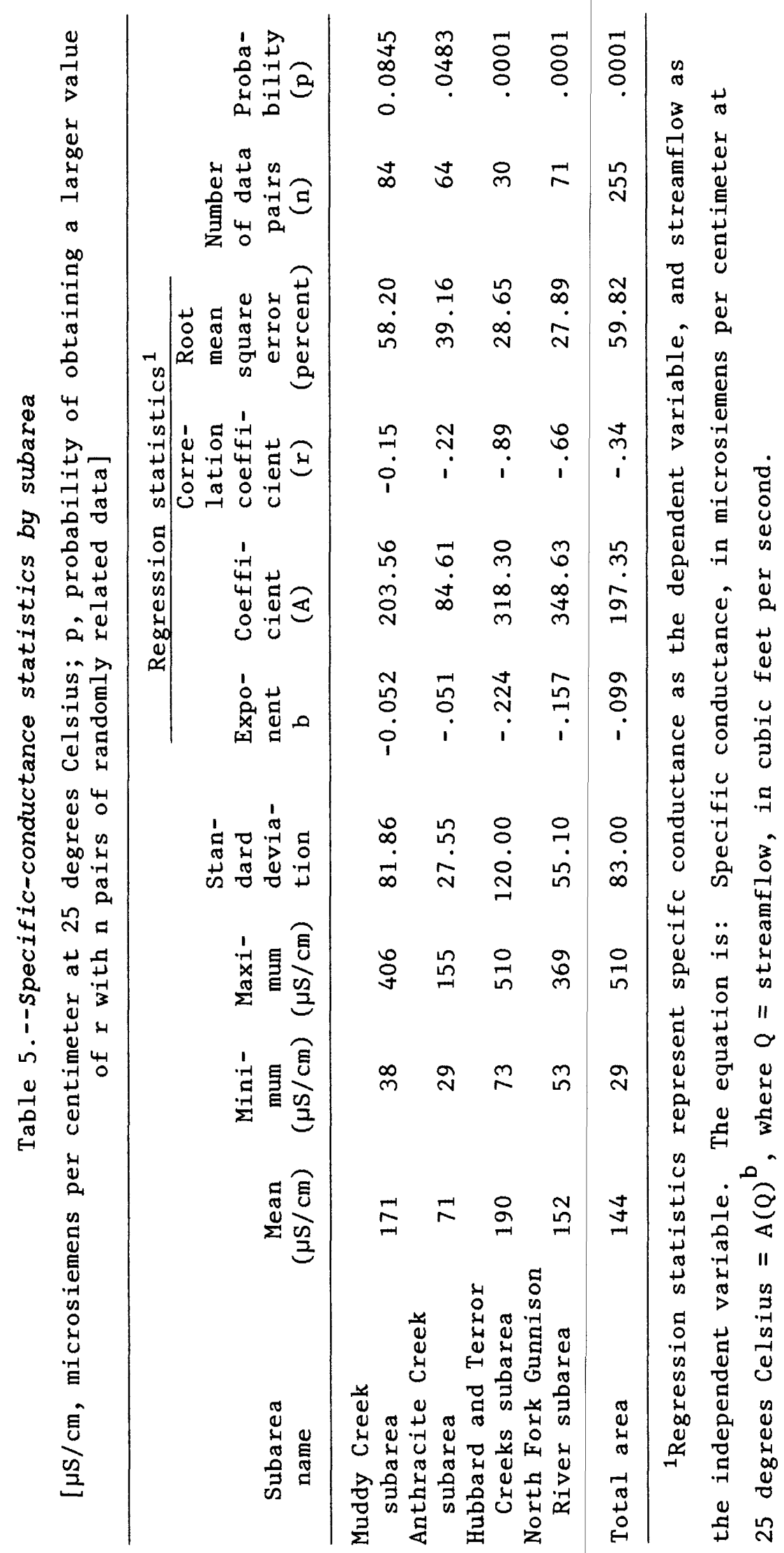




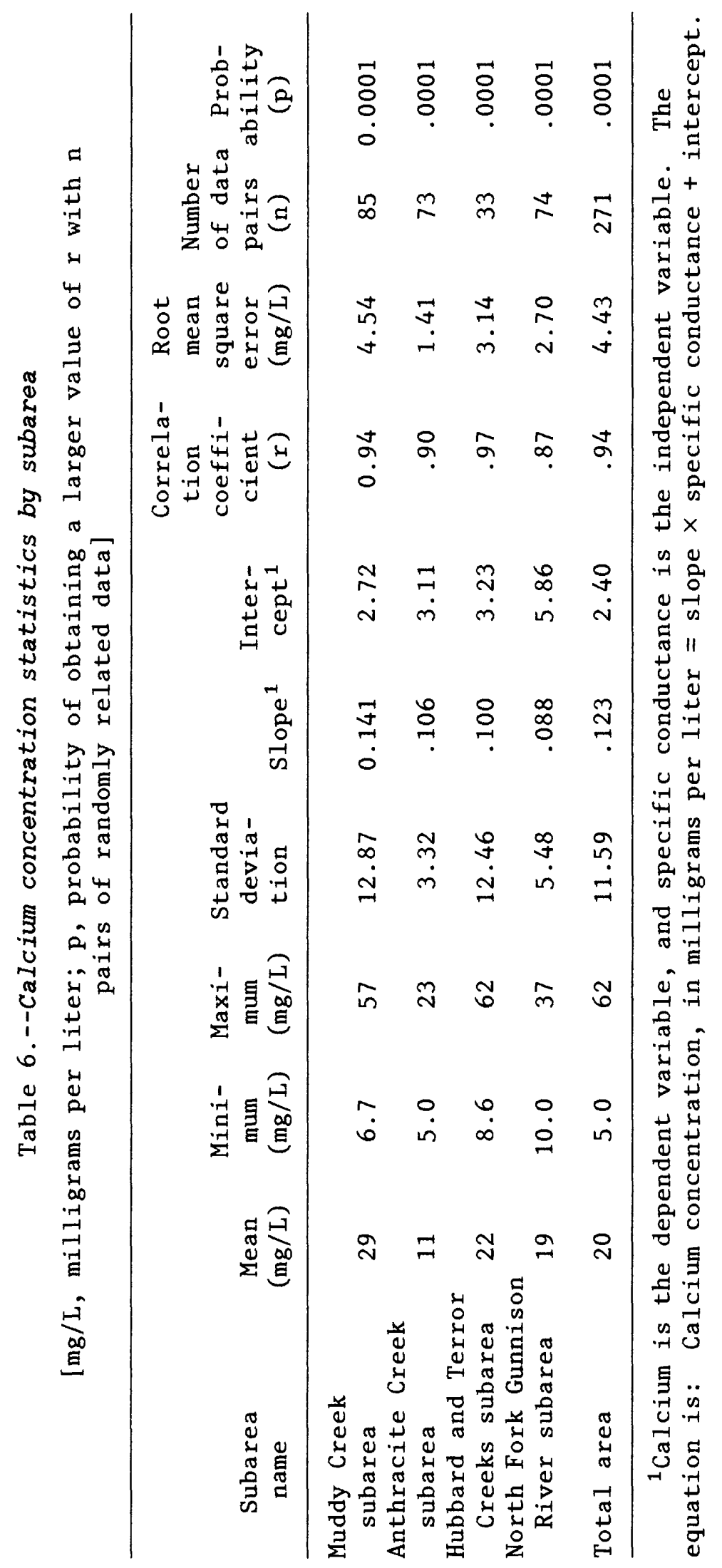




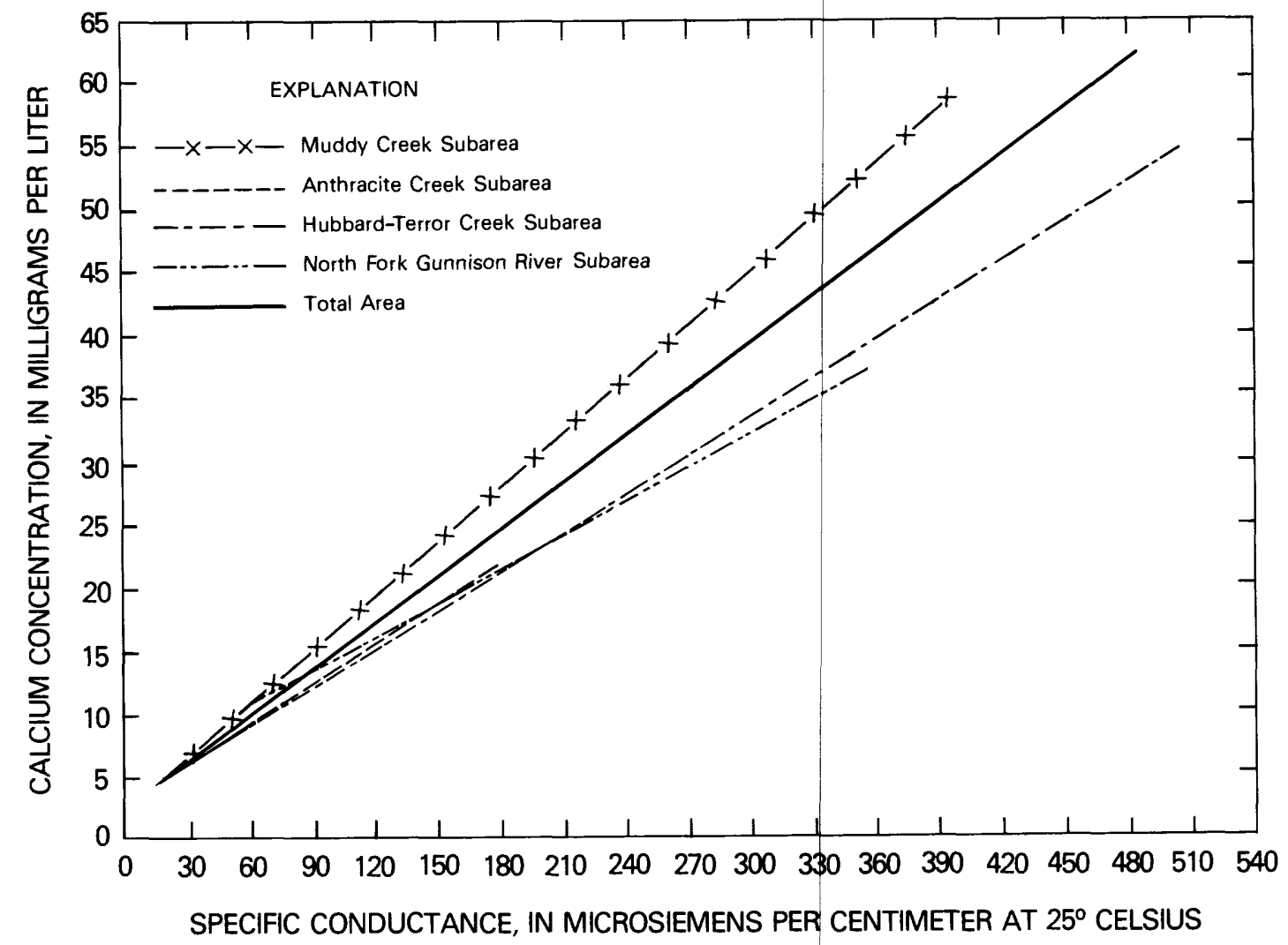

Figure 6.--Relation between specific conductance and calcium concentration by subarea. 


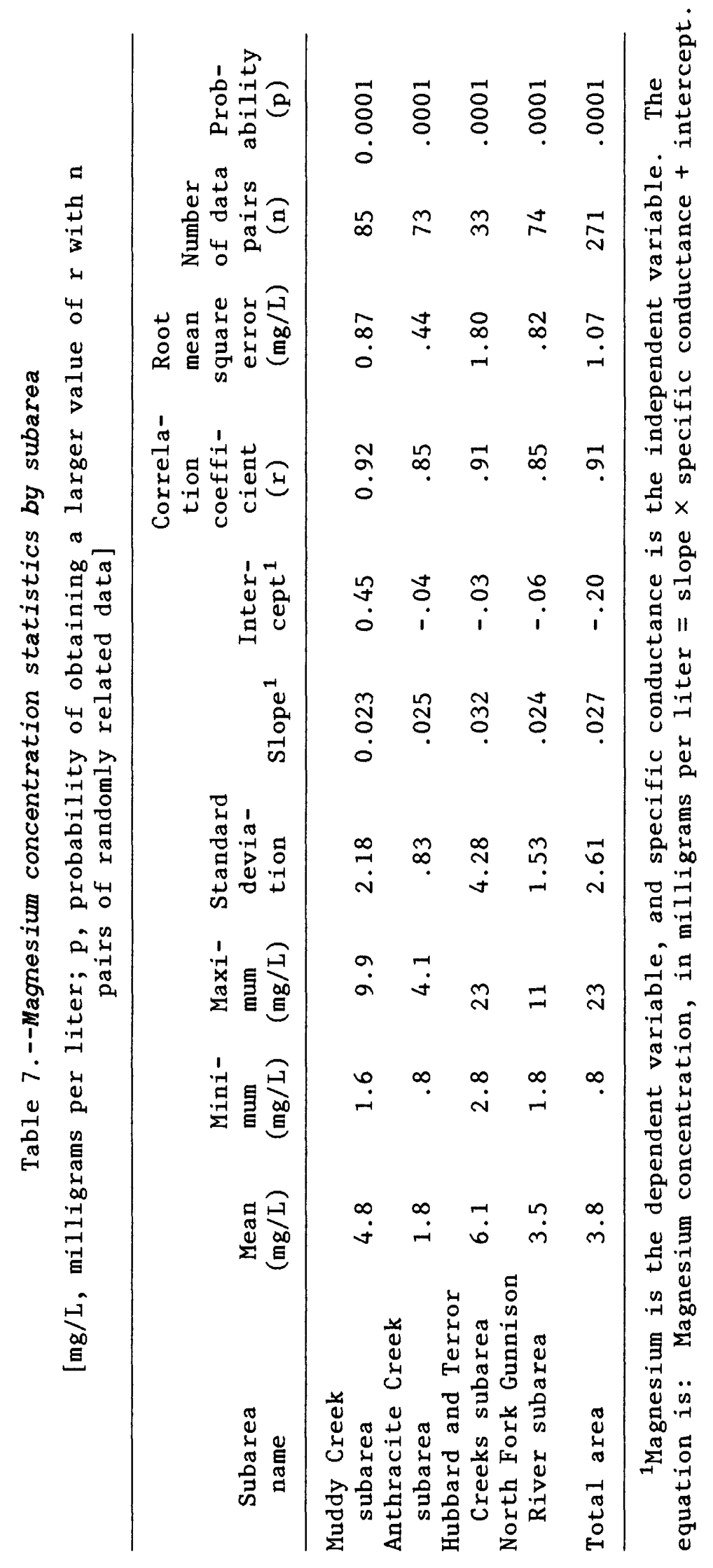




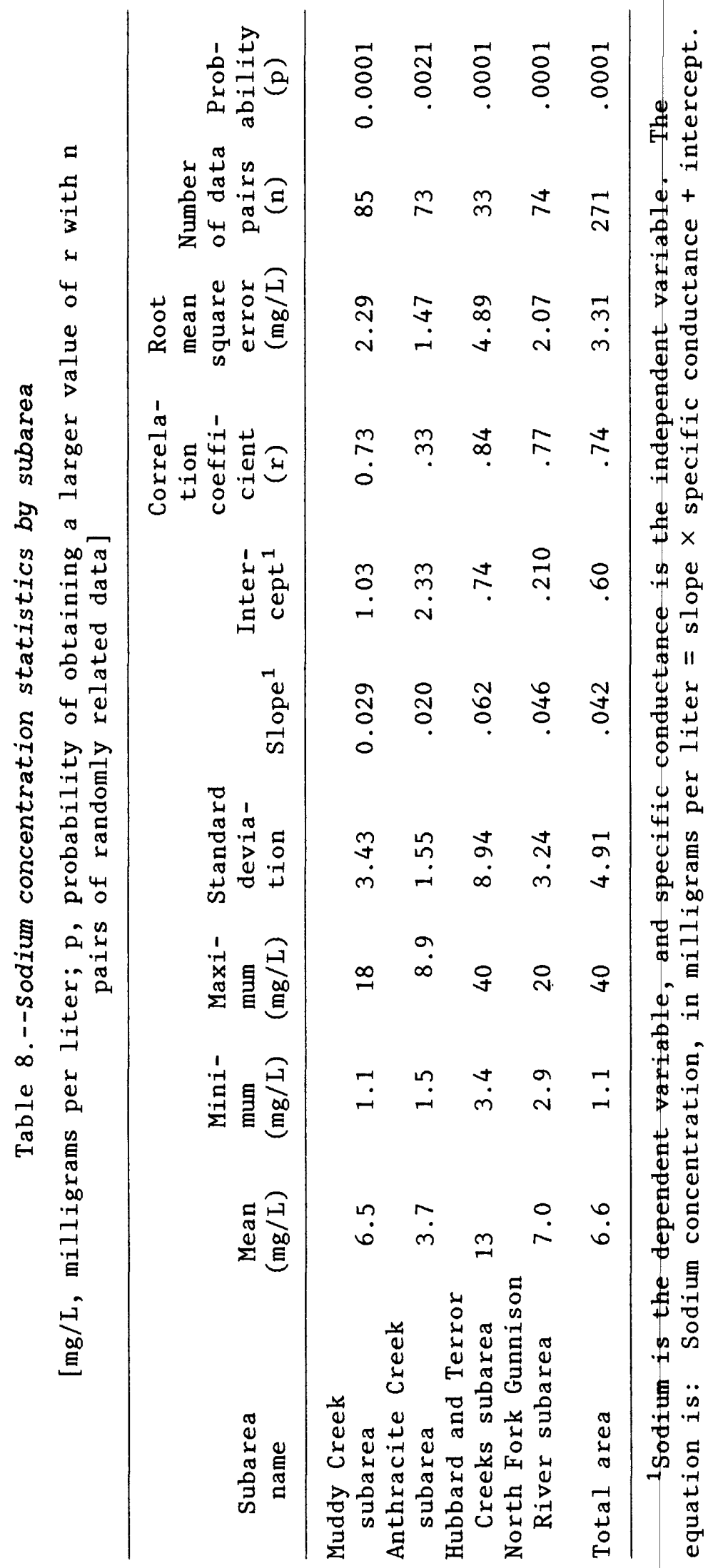




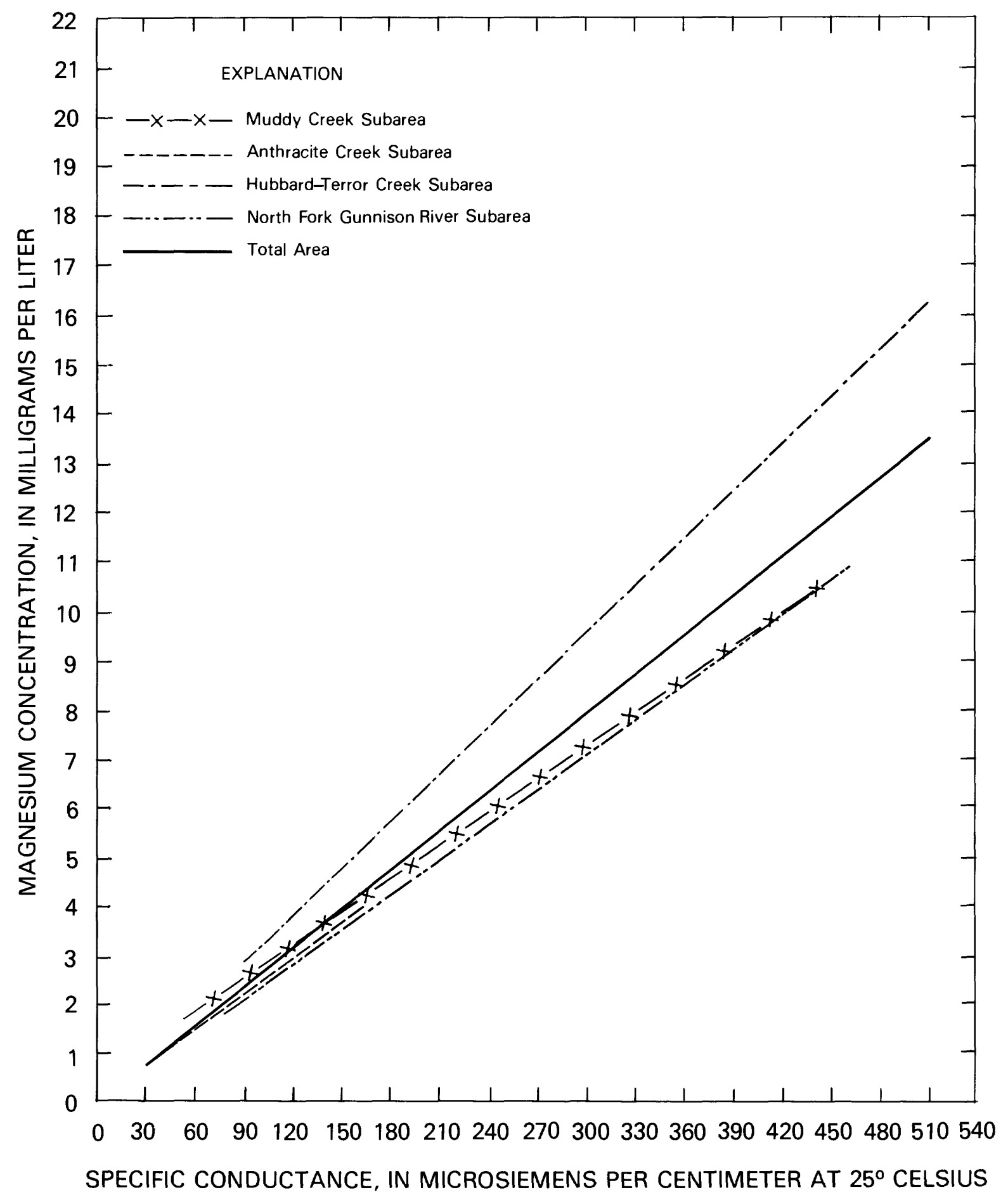

Figure 7.--Relation between specific conductance and magnesium concentration by subarea. 


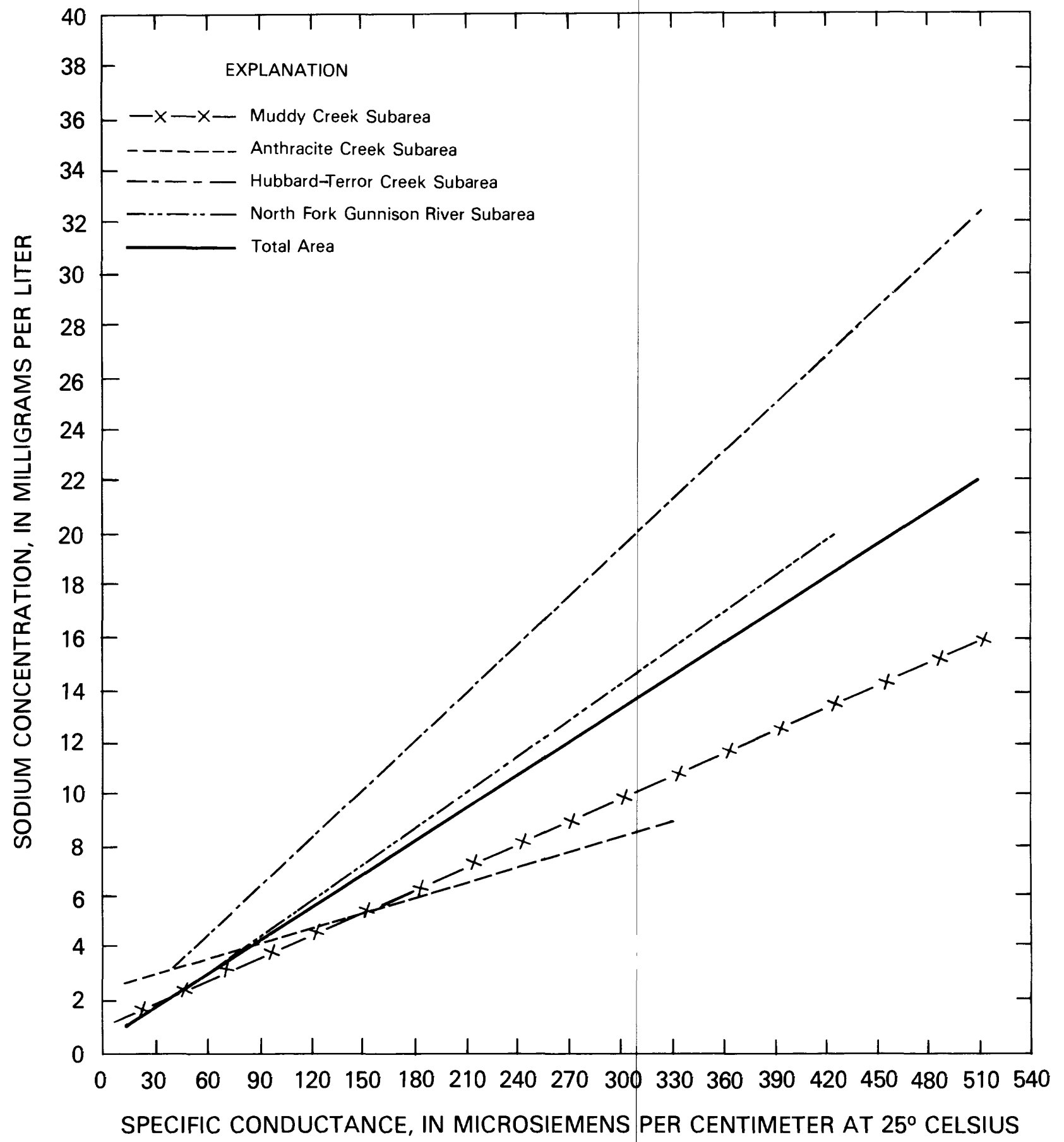

Figure 8.--Relation between specific conductance and sodium concentration by subarea. 
Compared to figure 7 , equations to predict sodium concentration from specific conductance plotted in figure 8 are more varied. However, for sodium concentration, the Hubbard and Terror Creeks subarea again has larger values and a steeper slope.

The mean, minimum, maximum, and standard deviation for alkalinity are presented in table 9. Hem (1970) defines alkalinity "as the capacity of the solution to neutralize acid." In most natural water, alkalinity is produced mostly by dissolved carbonate and bicarbonate ions. Measured alkalinity concentrations in the study area ranged from $7 \mathrm{mg} / \mathrm{L}$ to $220 \mathrm{mg} / \mathrm{L}$. Both maximum and minimum alkalinity concentrations for the study area were from the Hubbard and Terror Creeks subarea.

Regression-equation values to predict alkalinity from specific conductance for each subarea also are in table 9. These equations are plotted in figure 9, which indicates that, generally, alkalinity concentrations were larger in the Muddy Creek and Hubbard and Terror Creeks subareas, and smaller in the Anthracite Creek and North Fork Gunnison River subareas.

Mean minimum, maximum, and standard-deviation values are presented in table 10 for potassium, table 11 for chloride, table 12 for silica, and table 13 for sulfate. These constituents have small mean values, with the possible exception of sulfate values (table 13) in the Hubbard and Terror Creeks and North Fork Gunnison River subareas; these are discussed in later sections. Regression-equation values to estimate each constituent from specific conductance also are presented in tables 10 through 13 . However, as shown in these tables, generally the corelation coefficient is small, and use of many of the equations would provide questionable results. For equations represented in tables 10 through 13, equations with a small slope value indicate that the constituent has little relation with specific conductance. This especially is true for potassium (table 10) and chloride (table 11). For these constituents, the best estimate would be the mean concentration, with a range of plus and minus the standard deviation.

\section{Suspended Sediment and Trace Elements}

Within normal $\mathrm{pH}$ ranges, trace elements often are attached to sediment particles instead of dissolved, and a relation often can be developed between suspended-sediment and trace-element concentrations. Suspended-sediment concentration data are presented in table 14 for the subareas in the study area. The average suspended-sediment concentration for the entire area is approximately $214 \mathrm{mg} / \mathrm{L}$, with the Anthracite Creek and North Fork Gunnison River subareas having nearly equal concentrations, with an average of 126 $\mathrm{mg} / \mathrm{L}$. However, the Muddy Creek subarea has an average suspended-sediment concentration nearly 3 times larger $(361 \mathrm{mg} / \mathrm{L})$. The source of the larger suspended-sediment concentration is unknown, but probably is related to landslides and easily erodible soils.

Mean daily suspended-sediment discharges for the subareas also are included in table 14. The largest mean daily suspended-sediment discharge occurred at the station with the largest drainage area, the North Fork Gunnison River above Paonia (fig. 2, site 8) site (North Fork Gunnison River 


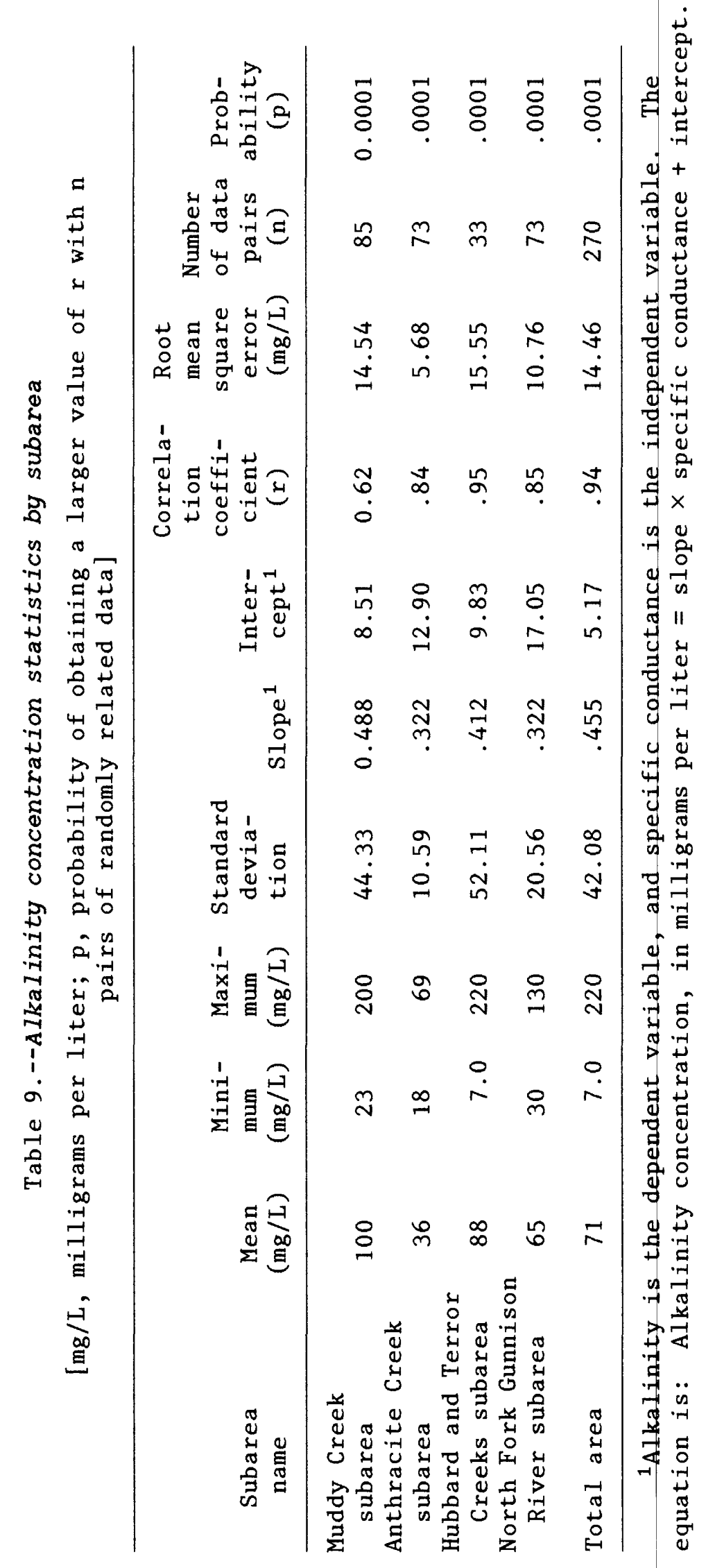




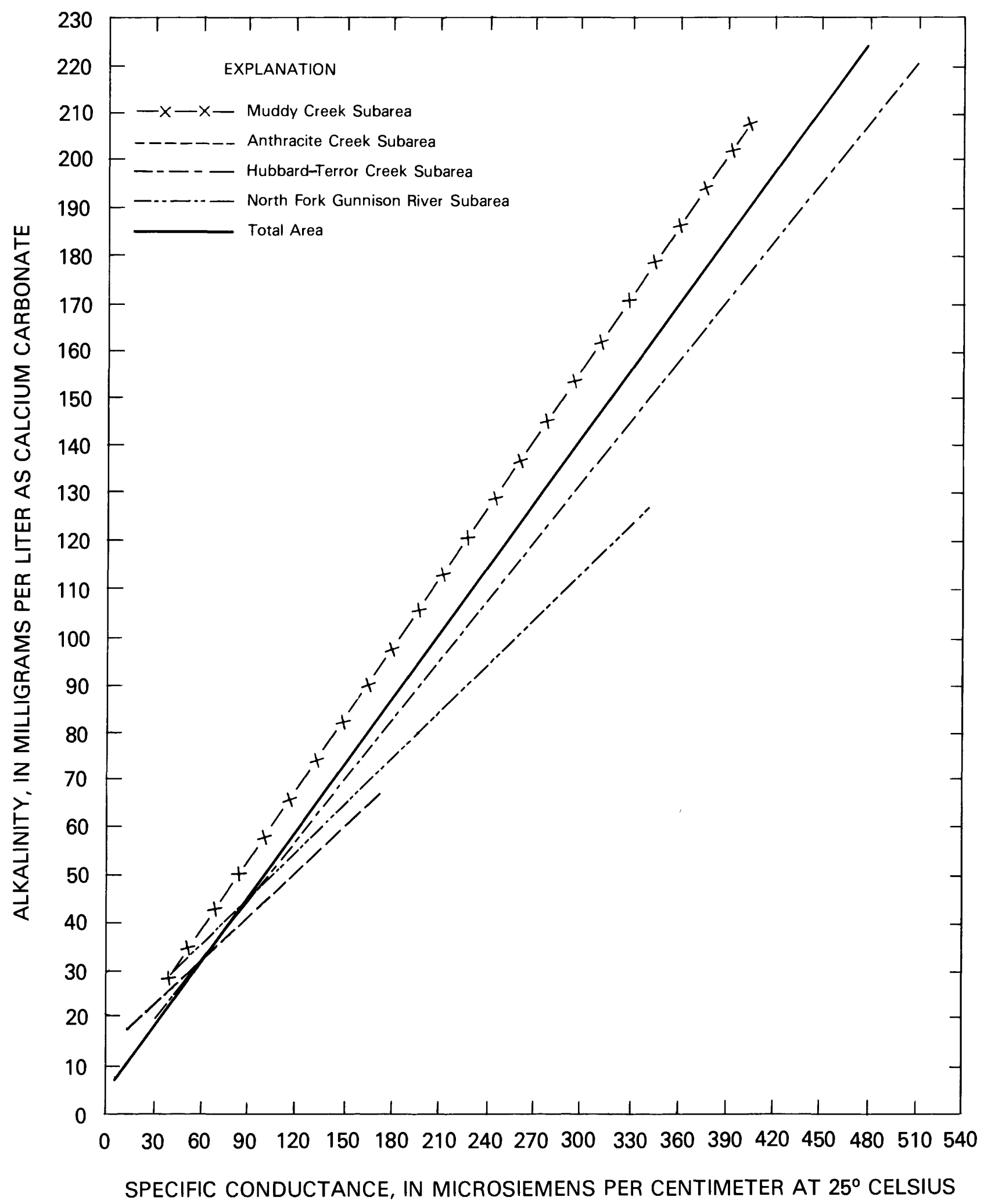

Figure 9.--Relation between specific conductance and alkalinity by subarea. 


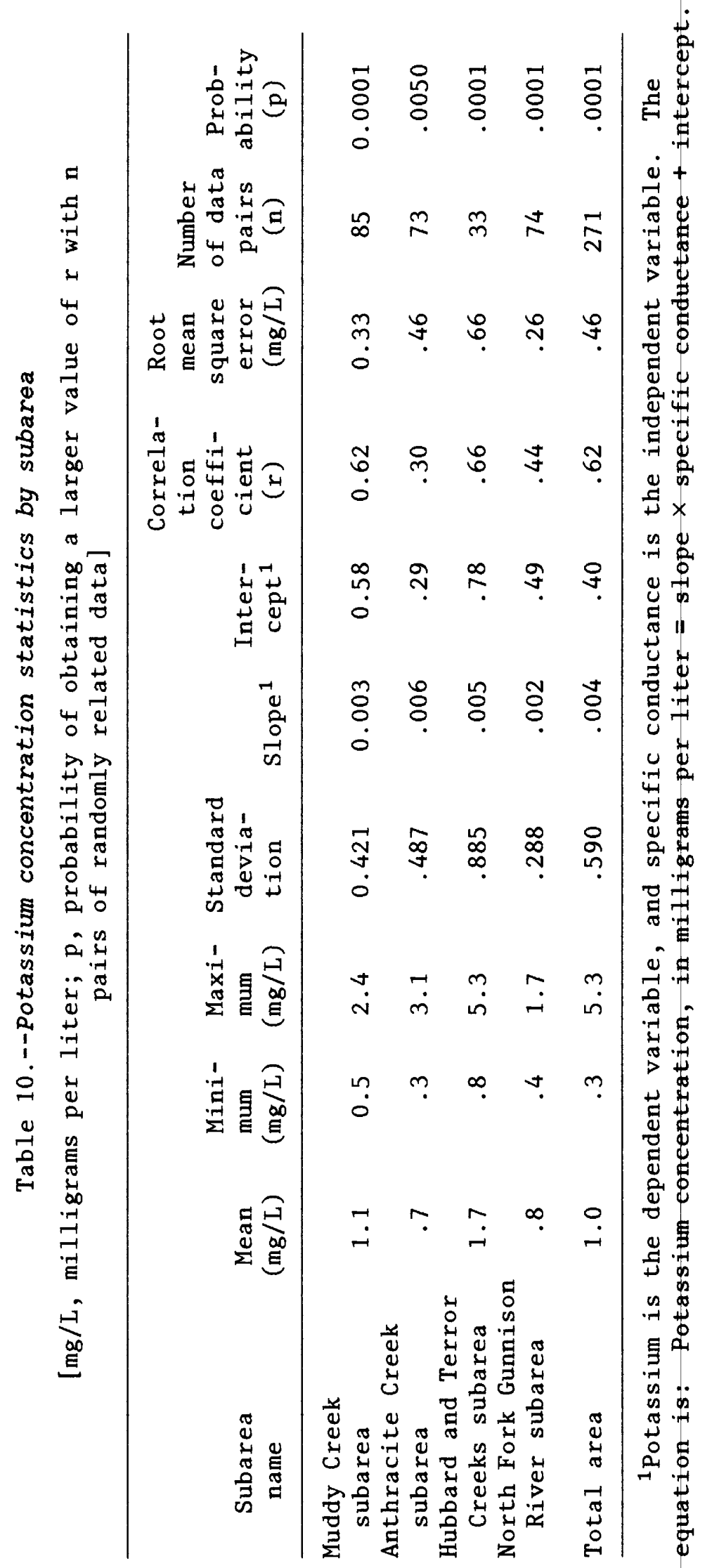




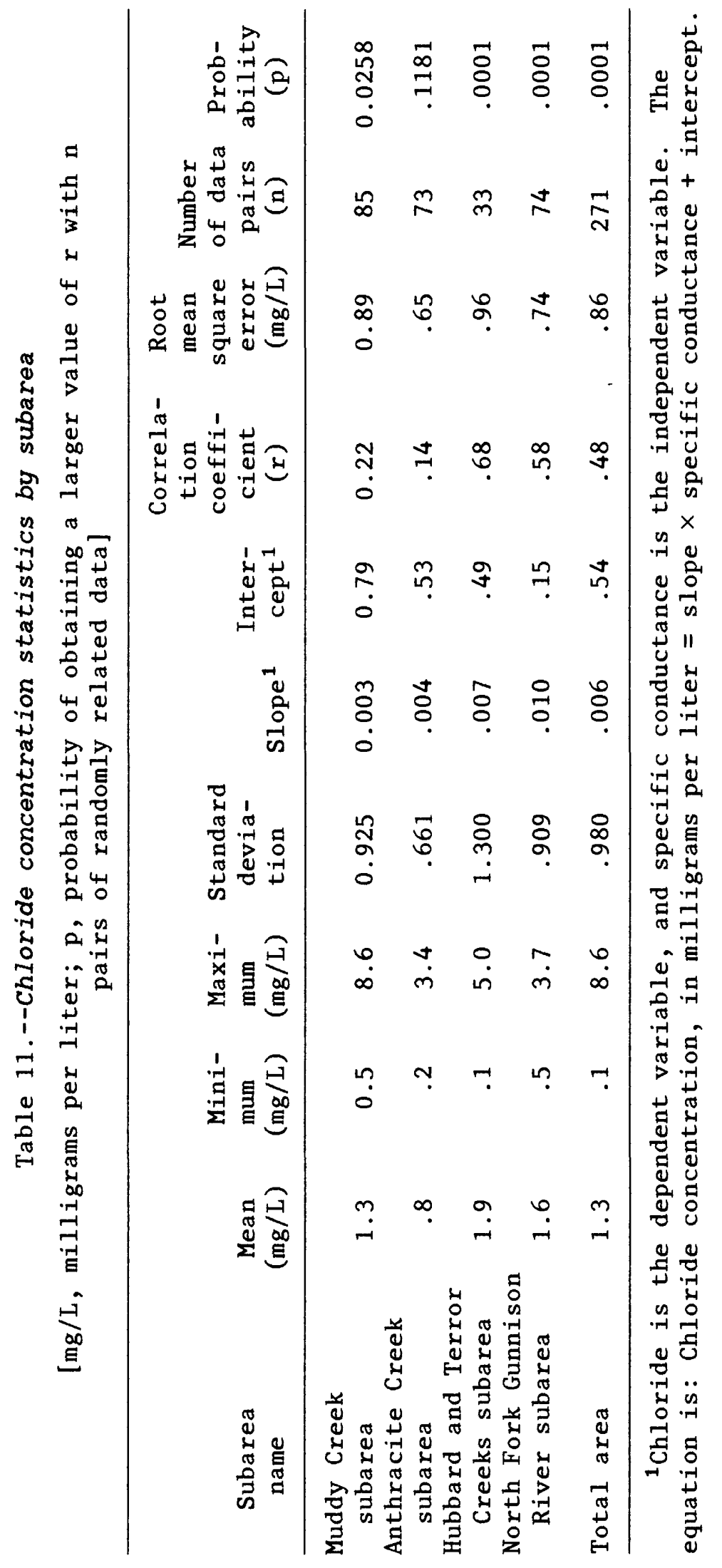




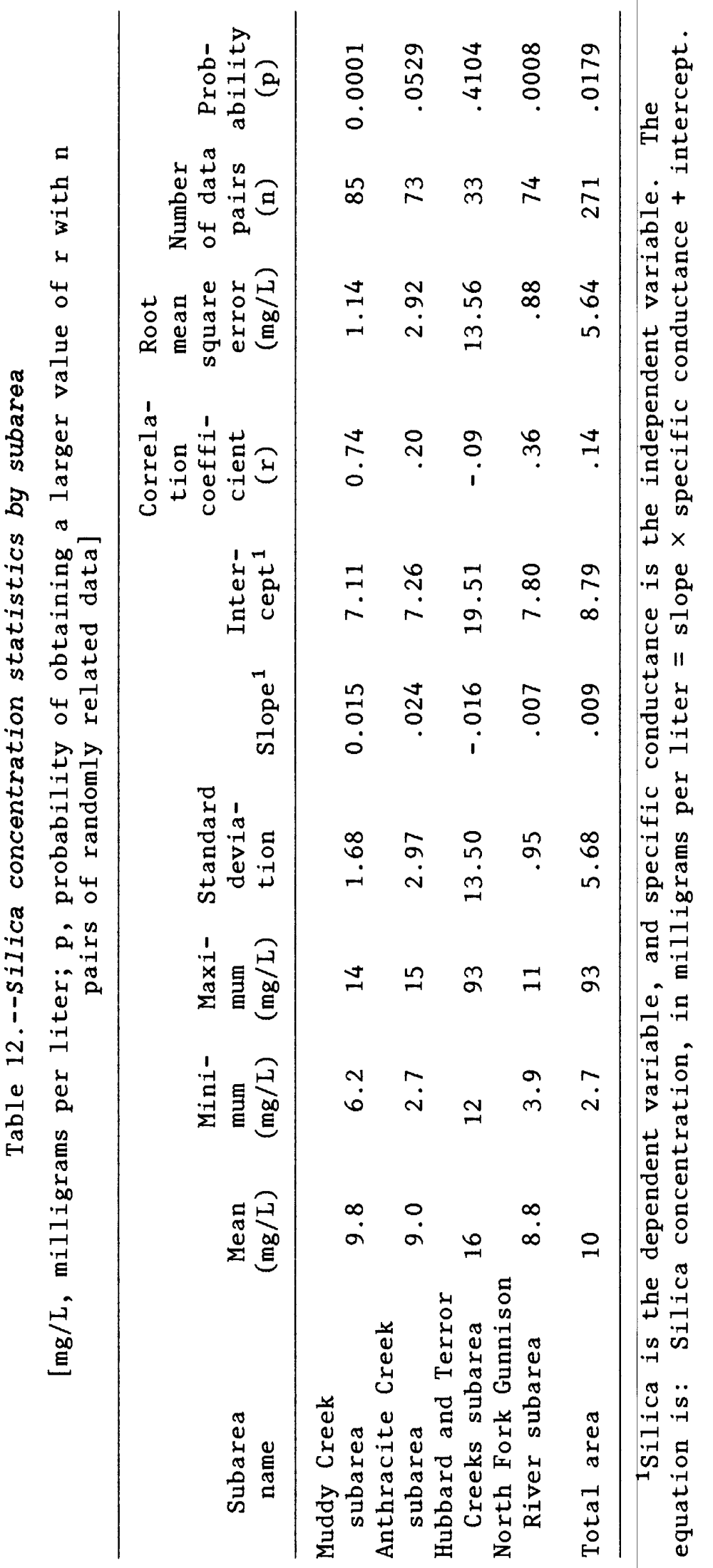




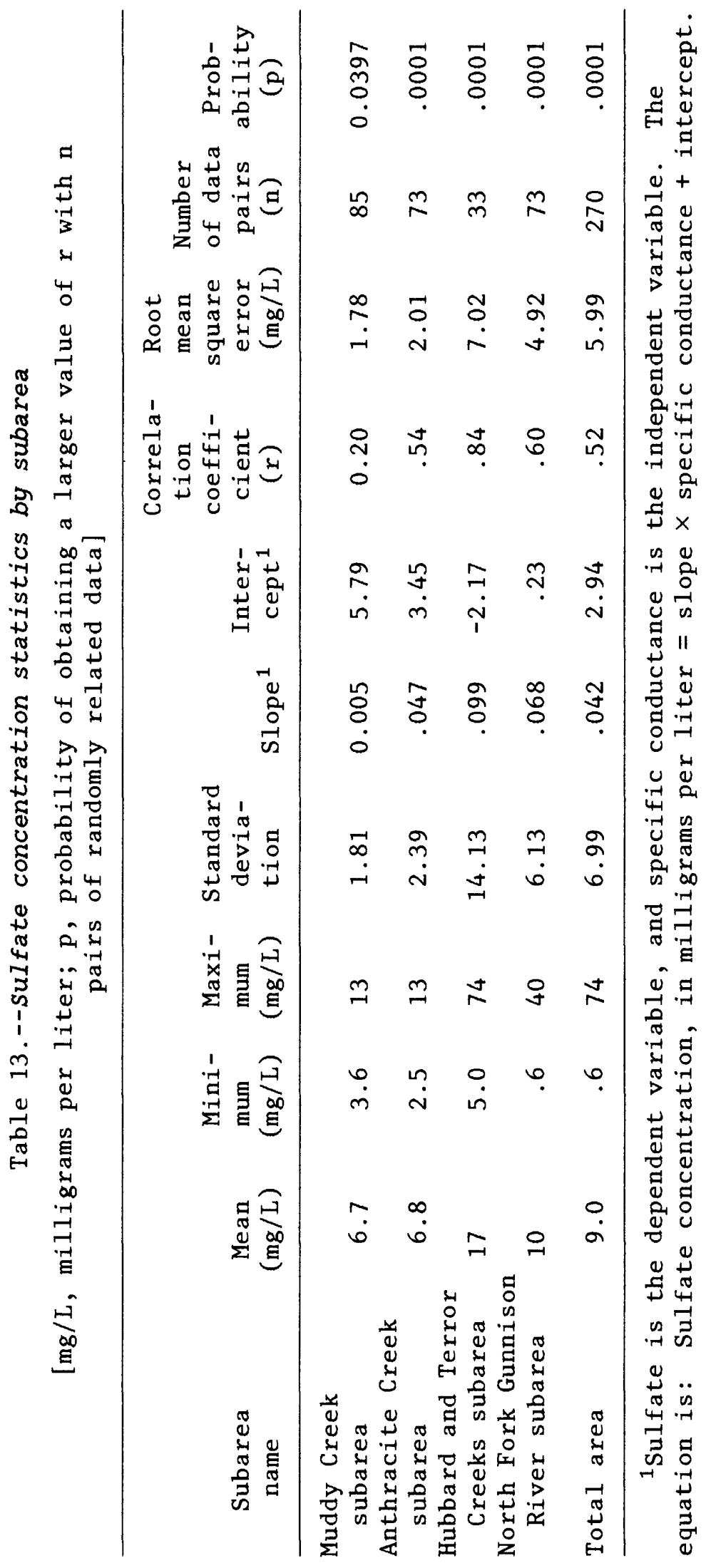


Table 14.--Suspended-sediment concentration statistics by subarea

[mg/L, milligrams per liter]

\begin{tabular}{|c|c|c|c|c|c|}
\hline $\begin{array}{l}\text { Subarea } \\
\text { name }\end{array}$ & $\begin{array}{c}\text { Mean } \\
(\mathrm{mg} / \mathrm{L})\end{array}$ & $\begin{array}{l}\text { Minimum } \\
(\mathrm{mg} / \mathrm{L})\end{array}$ & $\begin{array}{l}\text { Maximum } \\
(\mathrm{mg} / \mathrm{L})\end{array}$ & $\begin{array}{l}\text { Standard } \\
\text { deviation }\end{array}$ & $\begin{array}{l}\text { Mean daily } \\
\text { suspended- } \\
\text { sediment } \\
\text { discharge } \\
\text { (tons per } \\
\text { day) }\end{array}$ \\
\hline $\begin{array}{l}\text { Muddy Creek subarea } \\
\text { Anthracite Creek }\end{array}$ & 361 & 4 & 5,790 & 865.8 & 362 \\
\hline $\begin{array}{l}\text { subarea } \\
\text { Hubbard and Terror }\end{array}$ & 122 & 3 & 1,660 & 268.8 & 174 \\
\hline $\begin{array}{l}\text { Creeks subarea } \\
\text { North Fork Gunnison }\end{array}$ & 201 & 3 & 2,150 & 394.3 & 78 \\
\hline River subarea & 130 & 1 & 1,590 & 274.7 & 693 \\
\hline Total area & 214 & 1 & 5,790 & 561.4 & 355 \\
\hline
\end{tabular}

subarea), with a mean daily suspended-sediment discharge of $1,690 \mathrm{ton} / \mathrm{d}$. The smallest mean suspended-sediment discharge occurred at the Grouse Spring Creek near Marcellina Mountain (fig. 2, site 10) site (Anthracite Creek subarea), with a mean daily suspended-sediment discharge of 3.9 ton/d. This station has the smallest drainage area of all the sites where analyses were made.

The mean suspended-sediment concentrations and discharges were computed only from the 2 years of synoptically collected data. Subarea and total area mean values are the mean value of all data within that area.

Concentration statistics for total iron, manganese, and zinc for the subareas are presented in tables 15, 16, and 17. For these three trace elements, the Muddy Creek subarea had the largest mean concentrations, and the Hubbard and Terror Creeks subareas had the smallest mean concentrations. The most probable explanation for the Muddy Creek subarea having the largest trace-element concentrations is that it had the largest mean suspendedsediment concentration (table 14). Total-iron concentrations (table 15) appear large compared to the other trace elements analyzed; the cause for the large concentration is unknown, but it is most likely related to the natural large iron content in the area.

Regression-equation values to predict trace-element concentrations from suspended-sediment concentrations also are in table 15 for iron, table 16 for manganese, and table 17 for zinc. Prediction equation values for total-iron concentrations for the Muddy Creek and Anthracite Creek subareas are similar in slope and intercept (table 15); however, the Muddy Creek subarea values had maximum concentrations over 3 times larger than the Anthracite Creek subarea concentrations. 


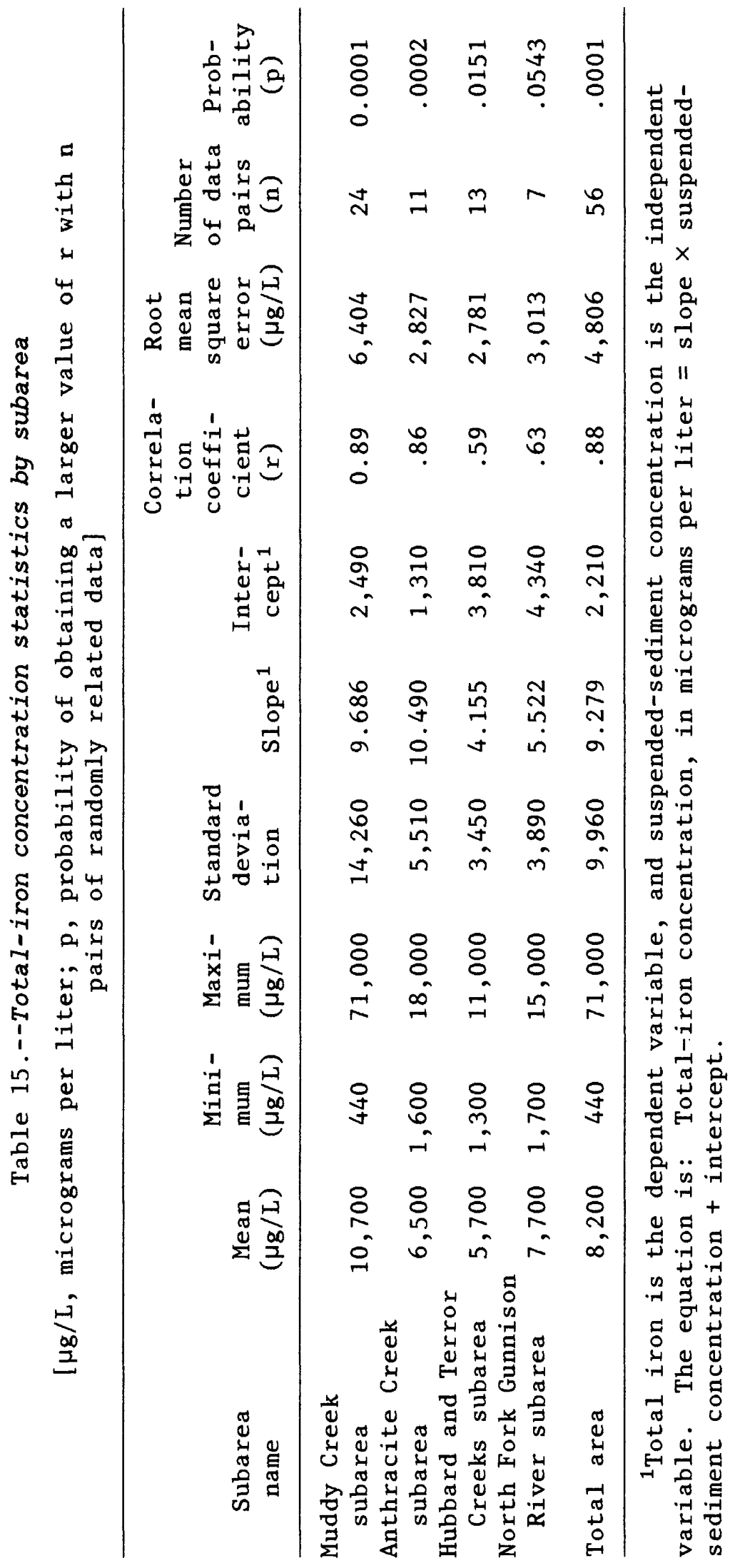


Statistics for total-lead and total-cadmium concentrations for the subareas are presented in table 18 and in table 19. Because correlation coefficients for the equations to estimate these trace-elements concentrations from suspended sediment generally are small, plots of these equations are not given. The largest mean total-lead concentration was found in the North Fork Gunnison River subarea; the largest maximum total-lead concentration was found in the Muddy Creek subarea (table 18).

As with total lead, the largest total-cadmium concentration analyzed was in the Muddy Creek subarea (table 19). In both tables 18 and 19, a value of $1 \mu \mathrm{g} / \mathrm{L}$ indicates the sample had trace-element concentration at or below detection limits.

\section{Effects of Paonia Reservoir}

Paonia Reservoir is located on Muddy Creek just upstream from the confluence of Muddy Creek and Anthracite Creek, where the combined flows become the North Fork Gunnison River. The reservoir had some effect on each waterquality constituent measured in the study from sites upstream (site 17) and downstream (site 14). These effects are summarized in table 20. Mean suspended-sediment discharge leaving the reservoir decreased by nearly 63 percent, with a mean suspended-sediment discharge of 1,395 ton/d entering the reservoir, but only 518 ton/d leaving the reservoir. These mean values only are from the two years of synoptically collected data.

This decreased suspended-sediment concentration leaving the reservoir had a major effect on the trace elements that attach to sediments. The mean trace-element concentration decreased by an average of nearly 67 percent downstream from the reservoir as compared to upstream (table 20).

Concentrations of major ions in the dissolved phase also decreased as the water flowed through the reservoir (table 20). Sulfate decreased the least (1.6 percent) and chloride decreased the most (approximately 22 percent) downstream from the reservoir as compared to upstream from the reservoir. Although mean chloride concentrations decreased by nearly 22 percent as water moved through the reservoir, the actual decrease was only $0.4 \mathrm{mg} / \mathrm{L}$. This decrease, as for many of the major-dissolved constituents, probably is related to the reservoir storage of low-concentration runoff. No samples were collected in the reservoir.

\section{Effects of Coal Mining}

General coal-mining effects on water quality have been known for some time. Pyritic materials, generally iron pyrite $\left(\mathrm{FeS}_{2}\right)$ are exposed to the atmosphere and water, and react to form ferrous sulfate $\left(\mathrm{FeSO}_{4}\right)$ and sulfuric acid $\left(\mathrm{H}_{2} \mathrm{SO}_{4}\right)$. This breakdown of pyrite usually increases the concentration of sulfate, hydrogen ions, and iron in the water. Increased concentration of hydrogen ions results in low $\mathrm{pH}$, which is a common characteristic of many coal-mine drainage waters (Biesecker and George, 1966). Reaction of this low-pH water with carbonate materials decreases acidity (increases $\mathrm{pH}$ ) and increases dissolved-solids concentration. Thus, a measure of coal-mining effects on water quality is provided by examining dissolved-solids concentration, sulfate concentration, and $\mathrm{pH}$ or alkalinity. 


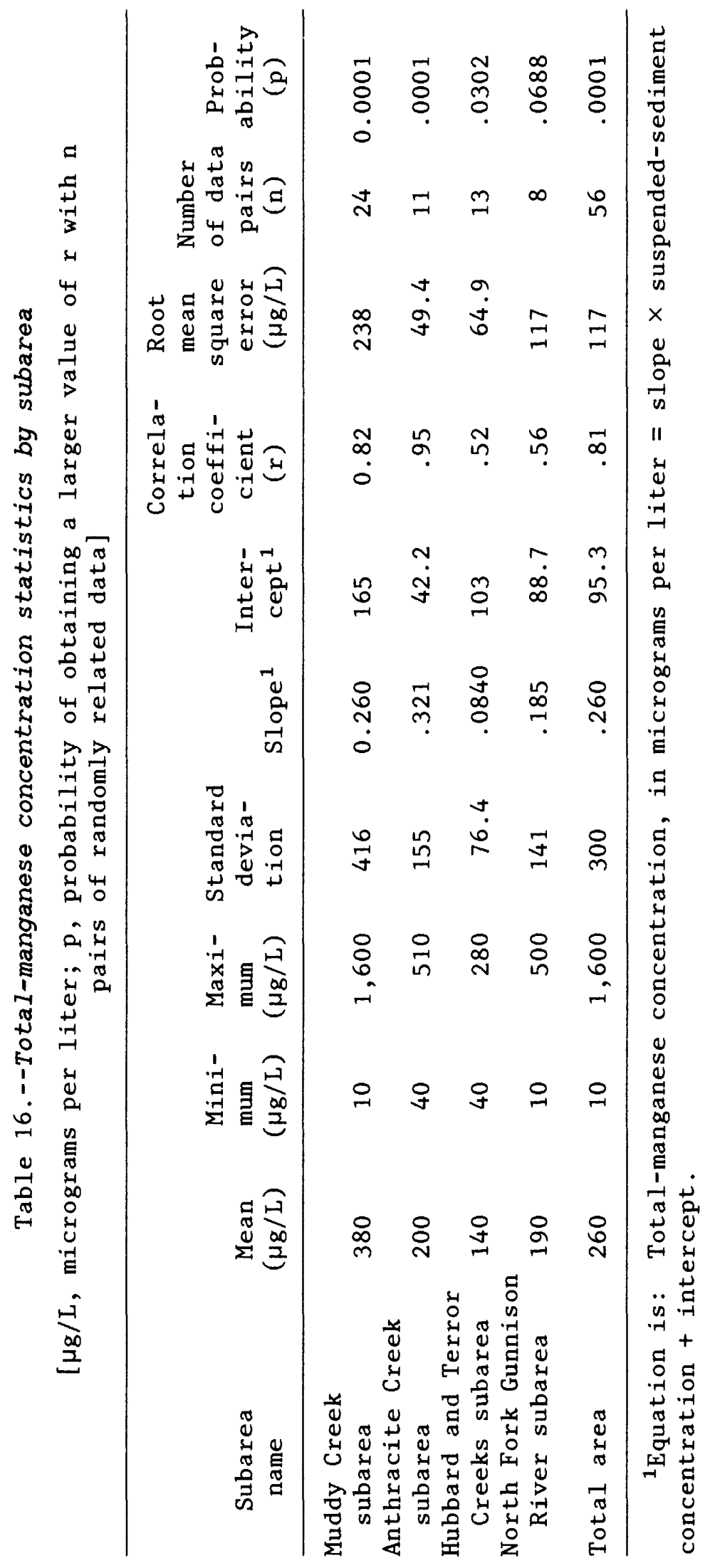




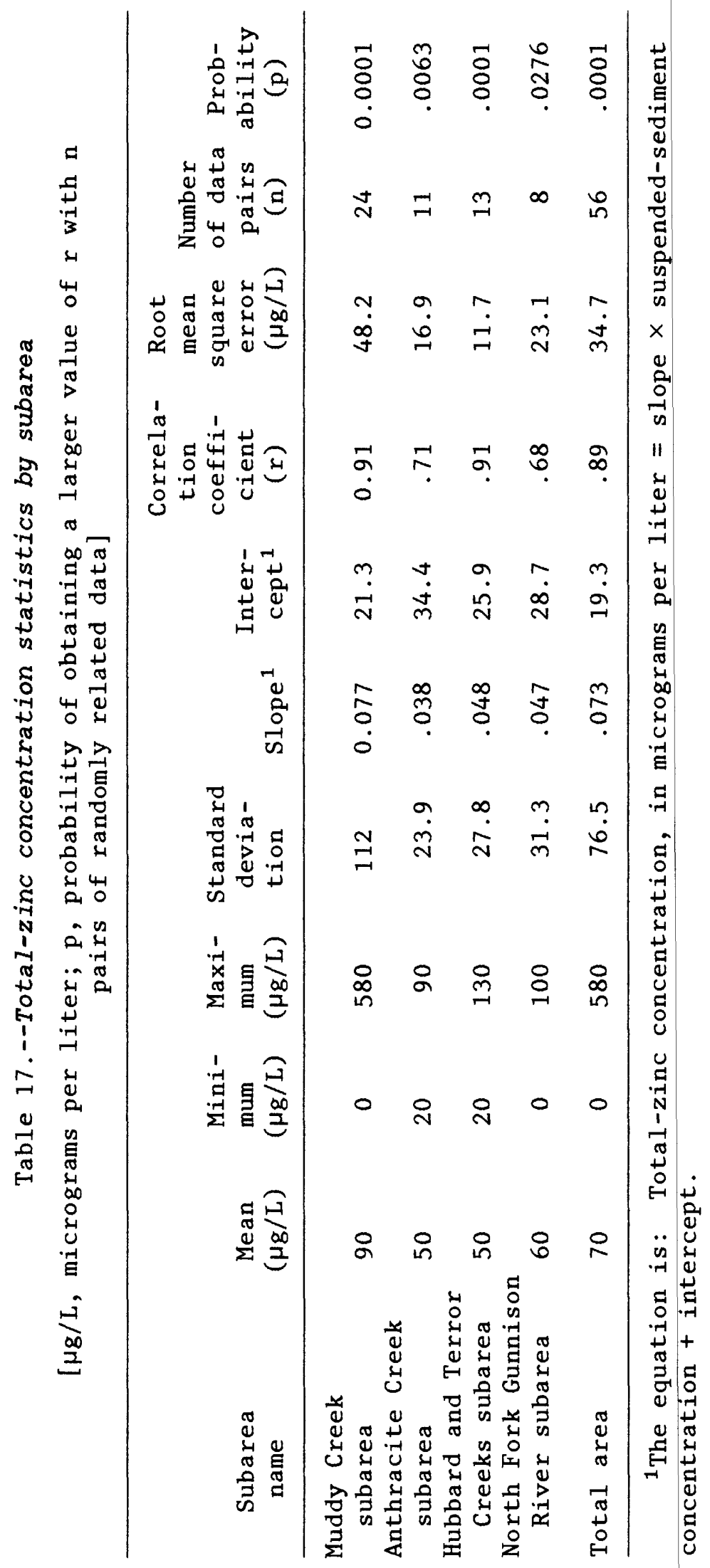




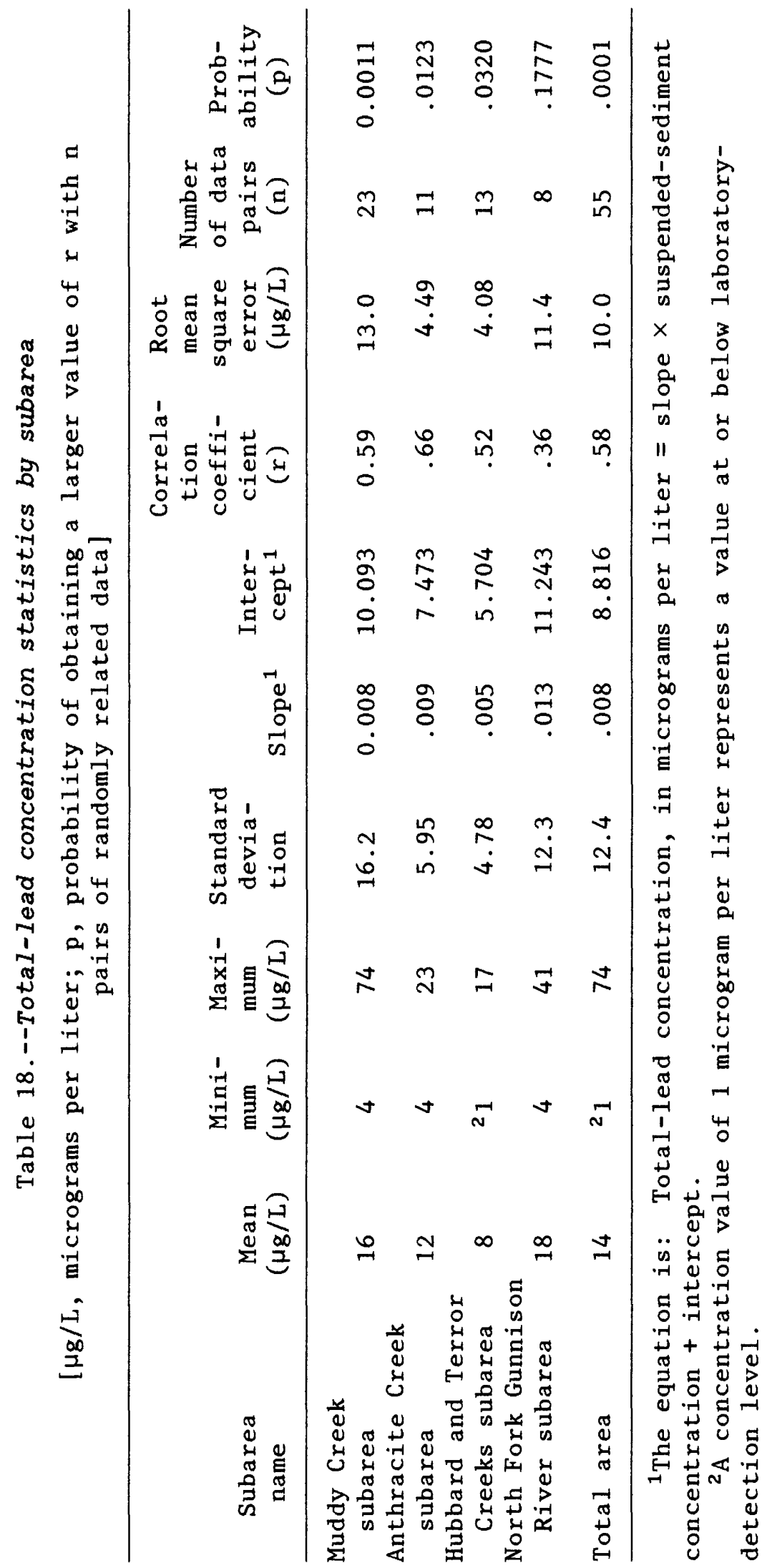




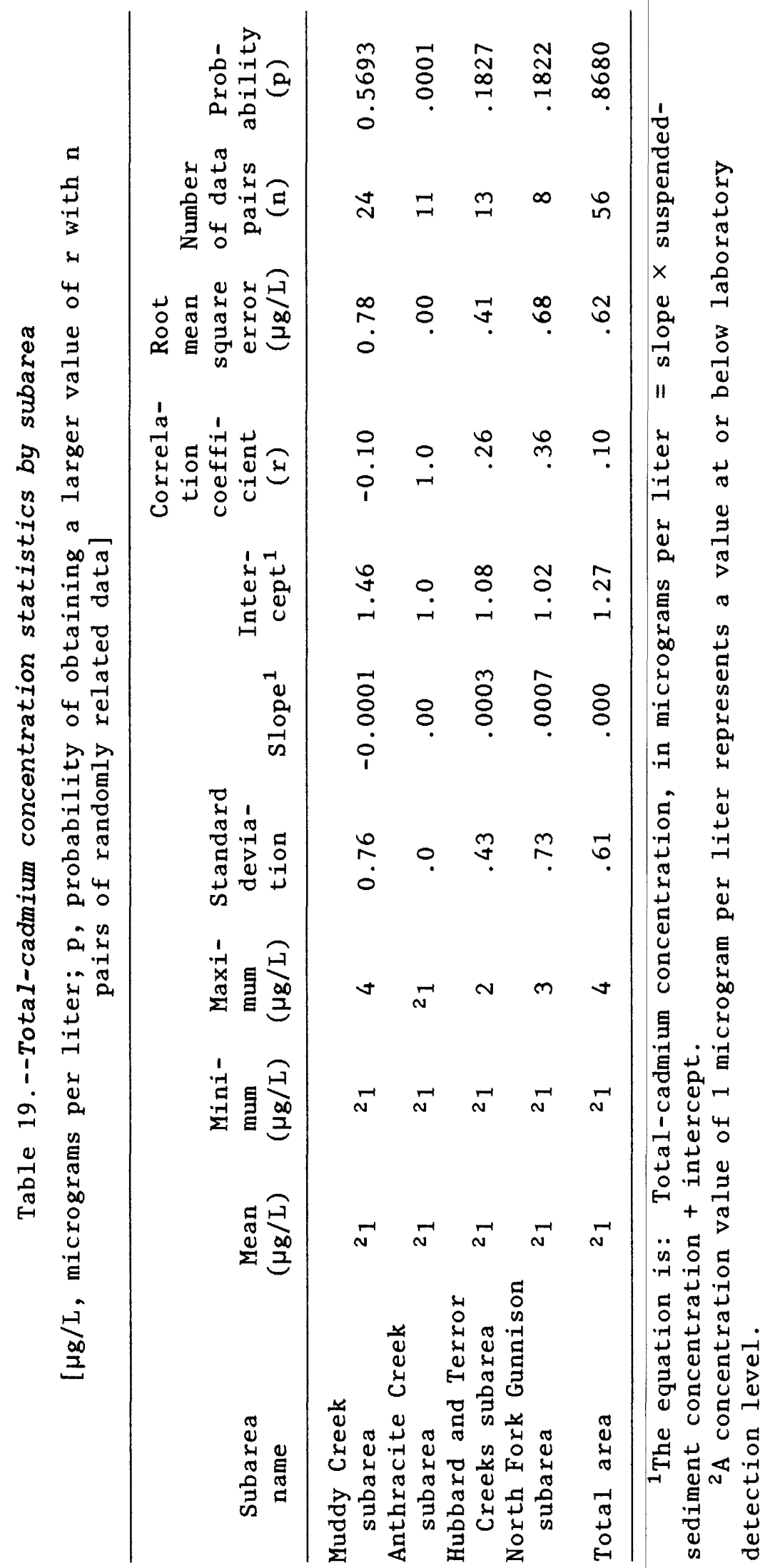




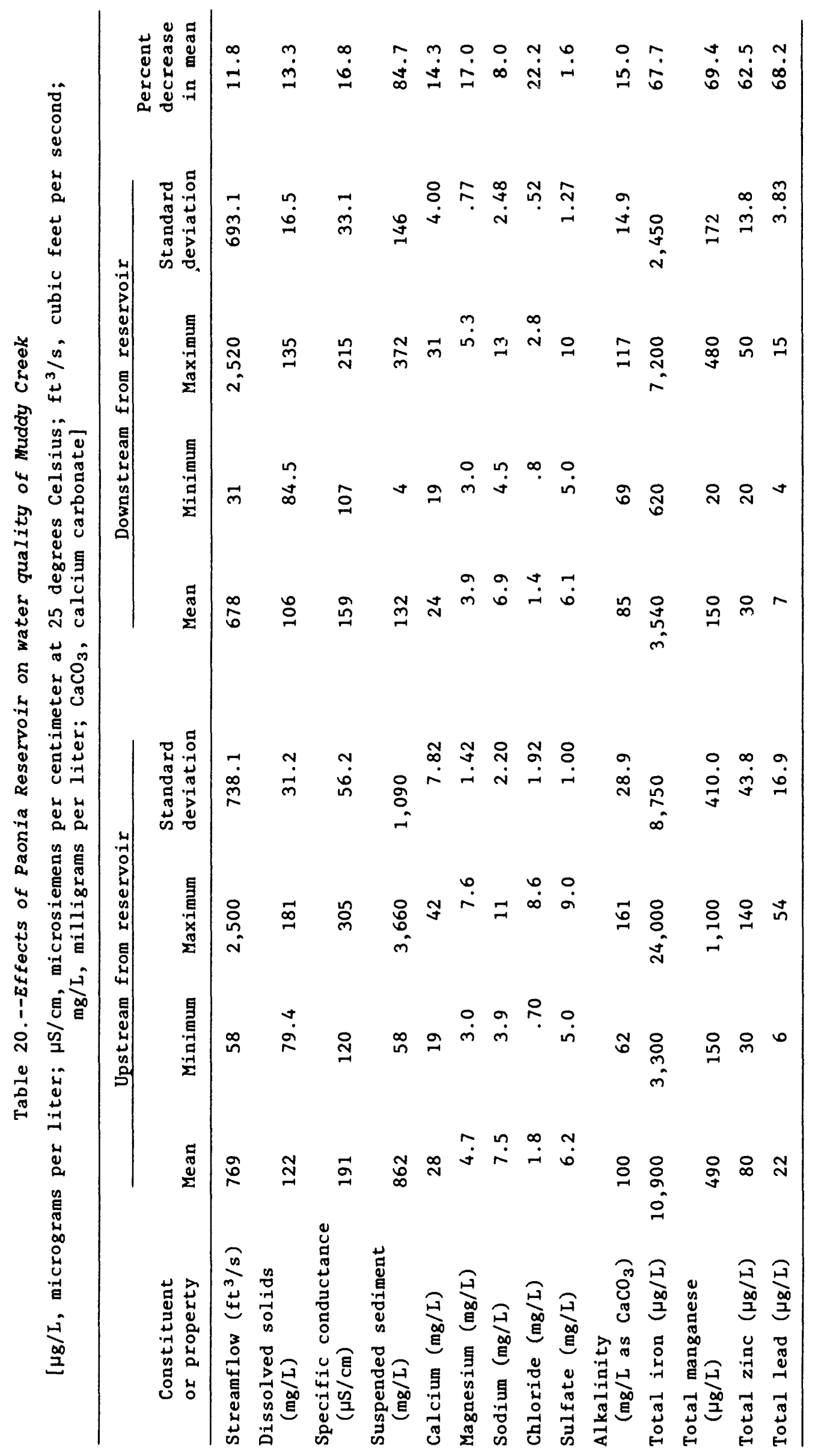


Water-quality sampling sites at lower Hubbard Creek near Bowie (fig. 2, site 11) and upper Hubbard Creek near Bowie (fig. 2, site 16) were established in an attempt to detect any changes in water quality that might be attributed to a coal mine located between these two sites. The relation between dissolved solids and streamflow for the two sites on Hubbard Creek are plotted in figure 10. Lower Hubbard Creek (downstream from mining) had a slightly larger concentration of dissolved solids at smaller streamflows than the upper

Hubbard Creek site. However, the increase was small and may not be related to mining, but may have been caused by downstream effects such as evaporation and ground-water inflow.

For the lower Hubbard Creek site, the regression equation plotted in figure 10 is:

$$
\begin{aligned}
\mathrm{DS} & =244.91 \mathrm{Q}^{-0.195} ; \text { and } \\
\mathrm{r} & =0.92 .
\end{aligned}
$$

For the upper Hubbard Creek site, the regression equation is:

$$
\begin{aligned}
\mathrm{DS} & =190.11(\mathrm{Q})^{-0.139} ; \text { and } \\
\mathrm{r} & =0.69 ;
\end{aligned}
$$

where

$$
\begin{aligned}
\text { DS } & =\text { dissolved-solids concentration, in milligrams per liter; and } \\
Q & =\text { streamflow, in cubic feet per second. }
\end{aligned}
$$

Mean dissolved-solids concentration for the upper Hubbard Creek site was $128 \mathrm{mg} / \mathrm{L}$ and $137 \mathrm{mg} / \mathrm{L}$ for the lower Hubbard Creek site, a 7-percent increase.

Sulfate concentration histograms for the two sites on Hubbard Creek are shown in figure 11. Mean sulfate concentration at the lower Hubbard Creek site was $14.9 \mathrm{mg} / \mathrm{L}$ and, at the upper Hubbard Creek site was $11.1 \mathrm{mg} / \mathrm{L}$, a 36.4 percent increase. Although the lower Hubbard Creek site (downstream from mining) had some sulfate concentrations larger than the upper Hubbard Creek site (figure 11), it is unknown if the differences are because of coal mining or because of downstream effects from evaporation and ground-water inflow or a combination of the two. To determine the cause of the increased sulfate and dissolved-solids concentrations at the lower Hubbard Creek site, more detailed sampling would be required.

Generally, acid coal-mine drainage into streams causes alkalinity to decrease. However, in the Hubbard Creek drainage, this was not observed. The mean alkalinity concentration, as $\mathrm{CaCO}_{3}$, upstream from mining was $82 \mathrm{mg} / \mathrm{L}$ and downstream from mining was $95 \mathrm{mg} / \mathrm{L}$, an increase of 15.9 percent. These data, and the discussion of dissolved-solids and sulfate concentration, suggest that, in Hubbard Creek, coal mining had no appreciable effects on water quality. To obtain more definitive results, however, more detailed sampling would be needed, as discussed earlier. 


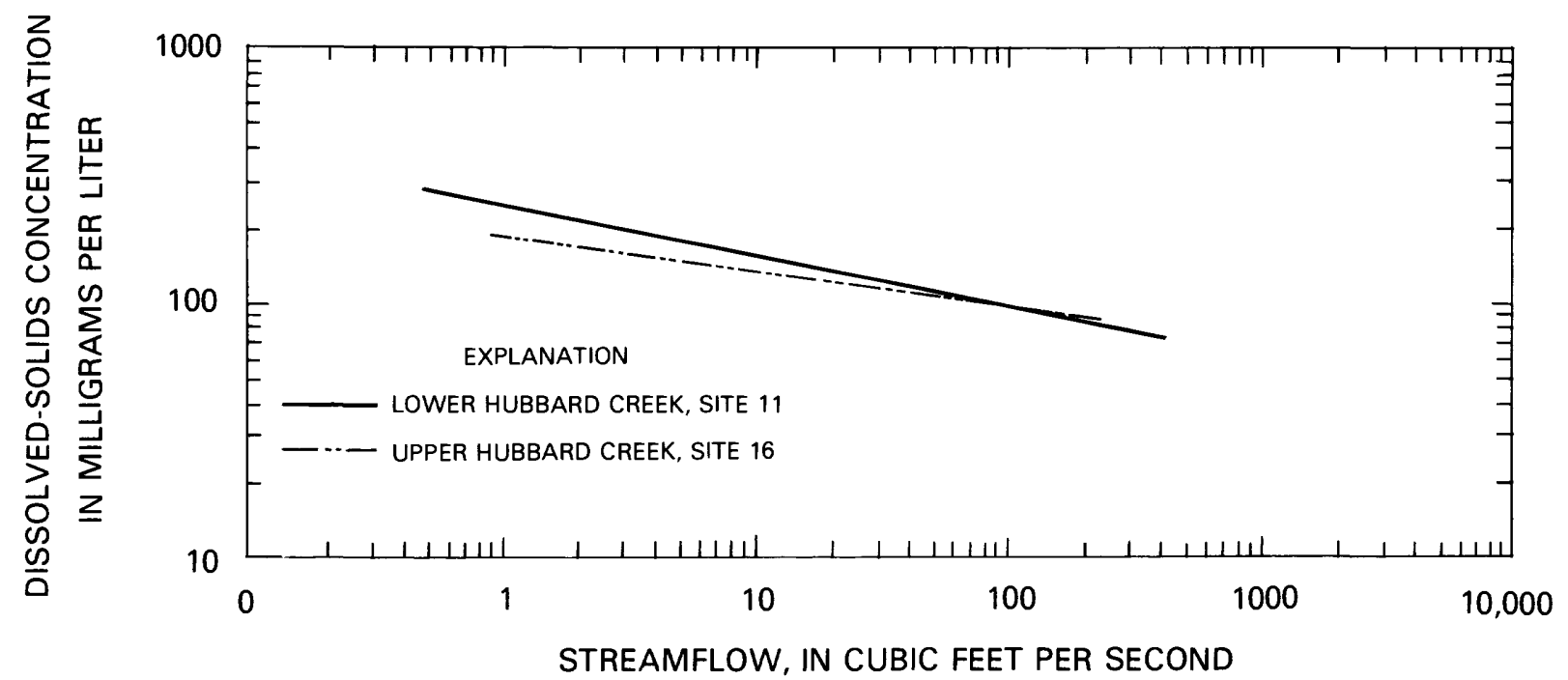

Figure 10.--Relation between streamflow and dissolved-solids concentration for upper and lower Hubbard Creek near Bowie.

\section{North Fork Gunnison River}

Most coal mining in the study area occurs along the banks of the North Fork Gunnison River. Because of an absence of bridges over the river and generally high streamflow, no water-quality sampling site could be established on the North Fork Gunnison River upstream from coal mining. However, waterquality sampling sites are on Muddy Creek (fig. 2, site 14) and Anthracite Creek (fig. 2, site 13), upstream from the convergence of these two streams, where they form the North Fork Gunnison River. Using an equation that weights the concentration by flow, estimates for concentrations of dissolved solids, sulfate, and alkalinity were made for the point of convergence of the two streams. The equation used was:

$$
c_{3}=\frac{Q_{1} C_{1}+Q_{2} C_{2}}{Q_{1}+Q_{2}} \text {, }
$$




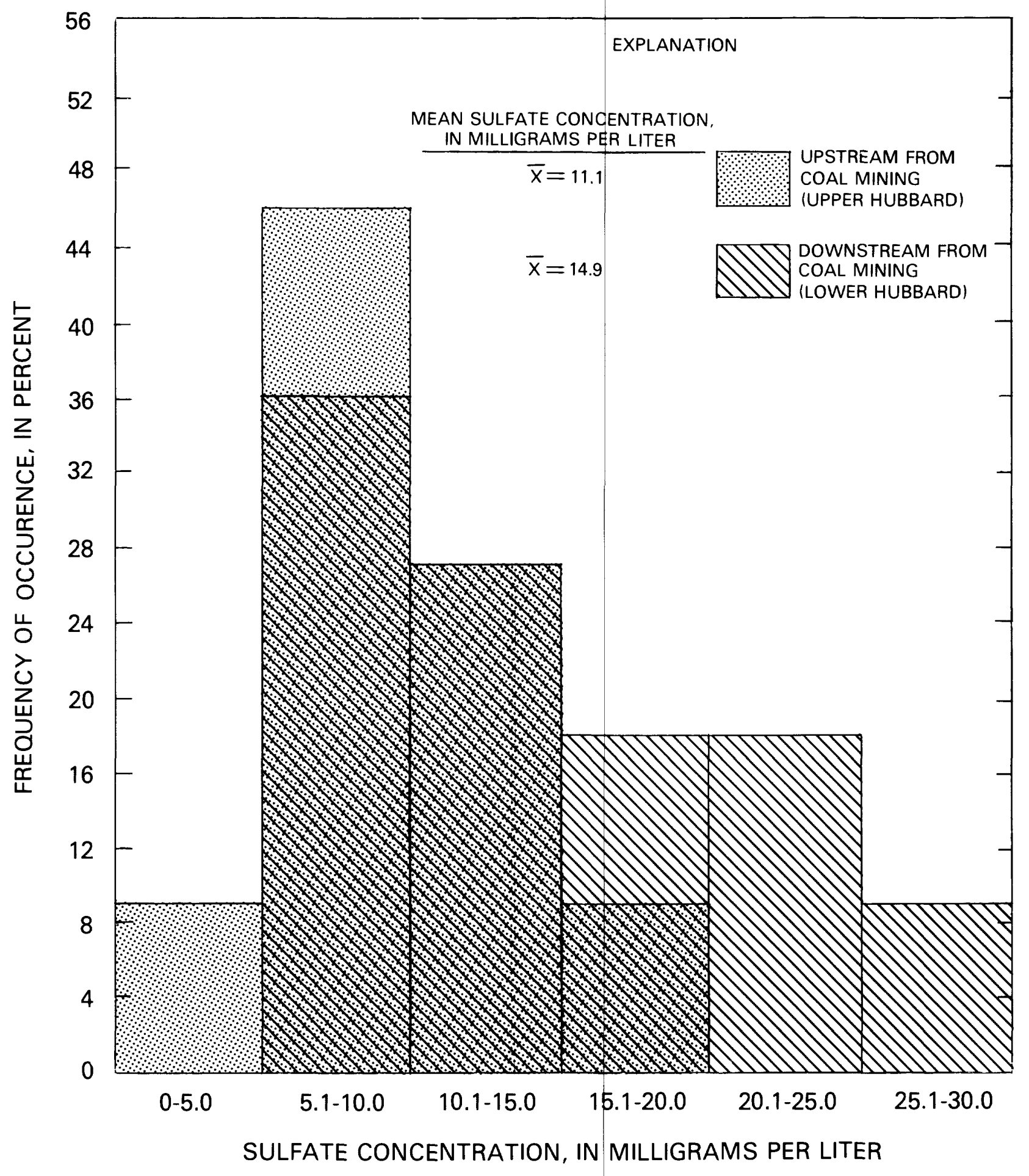

Figure 11.--Frequency of occurrence of sulfate concentrations for upper and lower Hubbard Creek, upstream and downstream from coal-mining activities. 
where

$$
\begin{aligned}
& \mathrm{Q}_{1}=\text { streamflow for Muddy Creek below Paonia Reservoir (fig. 2, } \\
& C_{1}=\text { concentration of the specific constituent for Muddy Creek } \\
& \text { below Paonia Reservoir (fig. 2, site 14); and } \\
& \mathrm{Q}_{2}=\text { streamflow for lower Anthracite Creek near Somerset (fig. 2, }
\end{aligned}
$$

The equation was used to transfer constituent data to the convergence point, generally when samples were collected the same day at the two sites. The point of convergence of Muddy Creek and Anthracite Creek to form the North Fork Gunnison River is called the upper North Fork Gunnison River site in this report.

Mean dissolved-solids concentration for the North Fork Gunnison River above Paonia site was $102 \mathrm{mg} / \mathrm{L}$ and, for the upper North Fork Gunnison River site it was $75.6 \mathrm{mg} / \mathrm{L}$. At smaller streamflows, dissolved-solids concentration downstream from the mining site (North Fork Gunnison River above Paonia) tend to be larger than for the estimated data at the upper North Fork Gunnison River site. Although these data could be an indication of coal-mining effects on water quality, the dissolved-solids concentration is small, and too few data are available to define the cause of this increase.

Frequency of occurrence of sulfate concentrations for the North Fork Gunnison River above Paonia and for the upper North Fork Gunnison River sites are in figure 12. As for dissolved-solids concentration, the larger sulfate concentrations were at the North Fork Gunnison River above Paonia site, downstream from mining. However, as for dissolved-solids concentration, mean sulfate concentrations were small, and too few data exist to determine the cause for the increase in sulfate concentrations at the site downstream from mining. As for Hubbard Creek, the increase in sulfate possibly is related to downstream effects discussed earlier. Although the mean sulfate concentration did increase more than 100 percent (from 7.0 to $14.2 \mathrm{mg} / \mathrm{L}$ ) between the two sites, other dissolved-constituent concentrations also increased substantially. For example, chloride concentrations increased more than 70 percent through the same stream reach.

As for Hubbard Creek, there were no major effects on alkalinity concentrations in the North Fork Gunnison River resulting from coal mining. Mean alkalinity, as $\mathrm{CaCO}_{3}$, was $57 \mathrm{mg} / \mathrm{L}$ for the upper North Fork Gunnison River site and was $70 \mathrm{mg} / \mathrm{L}$ for the North Fork Gunnison River above Paonia site, a downstream increase of 22.8 percent. 


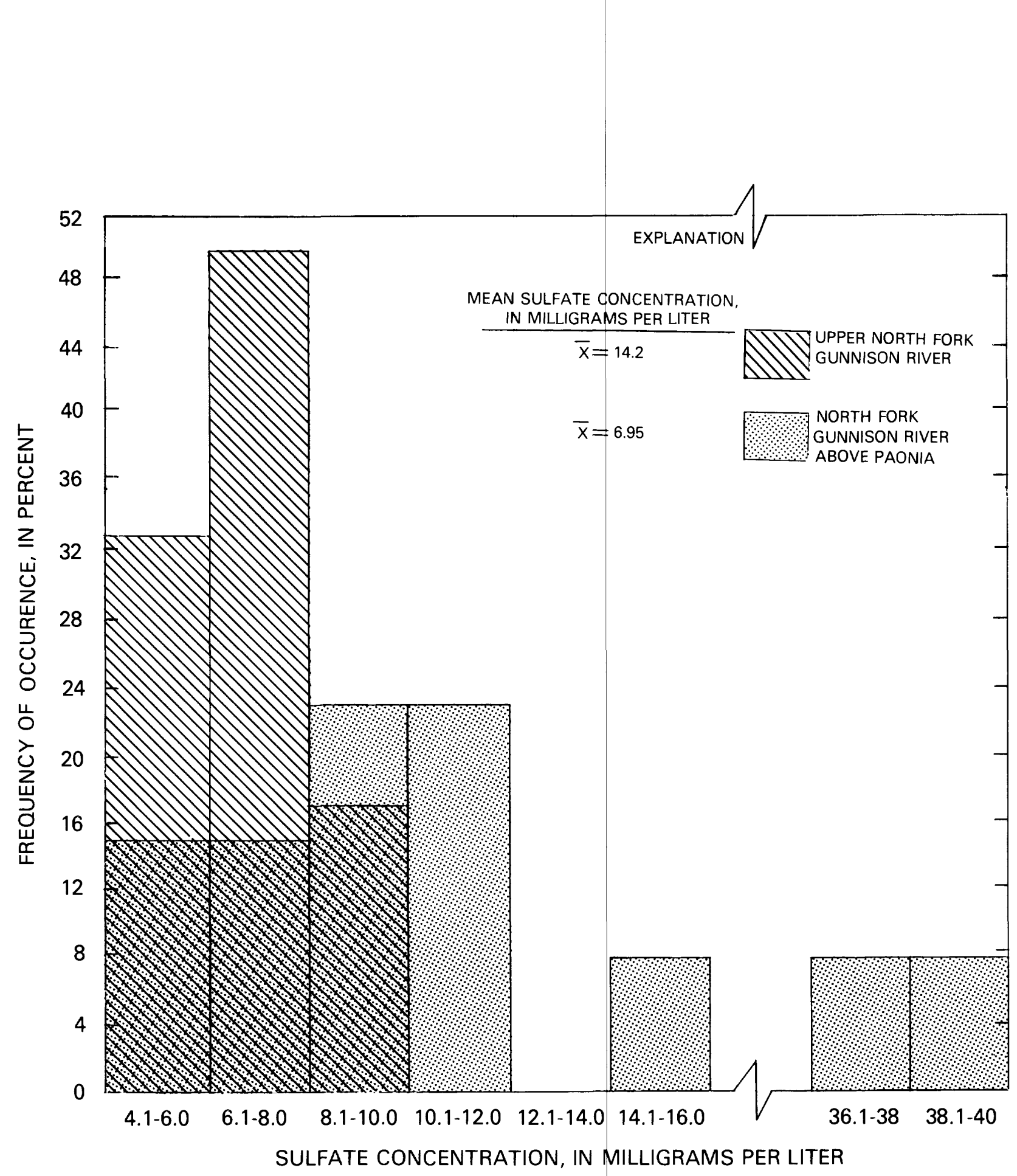

Figure 12.--Frequency of occurrence of sulfate concentrations for sites on the North Fork Gunnison River, upstream and downstream from coal-mining activities. 


\section{SUMMARY AND CONCLUSIONS}

Following evaluation of differences in geology and elevation, and statistical analyses of the water-quality data, the study area was divided into four subareas for data analyses. Location of the subareas included major watershed divides in the study area. These subareas were the Muddy Creek, Anthracite Creek, Hubbard and Terror Creeks, and the North Fork Gunnison River.

Dissolved-solids concentration and specific-conductance values from the study area were small. Dissolved-solids concentrations in the area ranged from $34 \mathrm{mg} / \mathrm{L}$ to $337 \mathrm{mg} / \mathrm{L}$ with the smallest mean concentration in the Anthracite Creek subarea $(55 \mathrm{mg} / \mathrm{L})$ and the largest mean concentration in the Hubbard and Terror Creeks subarea $(133 \mathrm{mg} / \mathrm{L})$. Mean dissolved-solids concentration for the study area was $97 \mathrm{mg} / \mathrm{L}$.

Dissolved constituents generally followed the same pattern as dissolvedsolids concentration and were, for the most part, small. For most dissolved constituents, mean concentrations were smallest in the Anthracite Creek subarea, and largest in the Hubbard and Terror Creeks subarea.

Suspended-sediment concentrations in the study area ranged from less than $1 \mathrm{mg} / \mathrm{L}$ to $5,790 \mathrm{mg} / \mathrm{L}$, with the smallest mean concentration in the Anthracite Creek subarea $(122 \mathrm{mg} / \mathrm{L})$, and the largest mean concentration in the Muddy Creek subarea $(361 \mathrm{mg} / \mathrm{L})$. Mean suspended-sediment concentration for the entire study area was $214 \mathrm{mg} / \mathrm{L}$. Mean suspended-sediment discharge for the study area was 355 ton/d, with the largest mean suspended-sediment discharge in the North Fork Gunnison River subarea (693 ton/d).

Of the trace elements analyzed, mean total concentrations were largest in the Muddy Creek subarea, and smallest in the Hubbard and Terror Creeks subarea. The study area appeared to have relatively large total-iron concentrations compared to other measured trace elements; the cause of this large concentration is unknown, but it probably is related to local geology.

Paonia Reservoir on Muddy Creek appeared to have substantial effects on suspended-sediment and trace-element concentrations. Mean suspended-sediment concentration decreased by nearly 6.5 times (from $862 \mathrm{mg} / \mathrm{L}$ to $132 \mathrm{mg} / \mathrm{L}$ ) between inflow and outflow of the reservoir and mean total trace-element concentrations decreased by an average of nearly 67 percent. The reservoir appeared to have only a minor effect on major-dissolved constituents, although the concentrations of all dissolved constituents decreased slightly from upstream to downstream from the reservoir.

The amount of data available is inadequate to determine what effects coal mining in the area may have on the water quality. Analyses of the data showed slight increases in alkalinity, sulfate, and dissolved-solids concentrations, but it is unknown if these increases were caused by coal-mining activities or downstream effects such as evaporation and ground-water inflow. More data are needed to determine what effects coal-mining activities in the area may have on the water quality. 


\section{REFERENCES}

Biesecker, J. E., and George, J. R., 1966, Stream quality in Appalachia as related to coal-mine drainage, 1965: U.S. Geological Survey Circular $526,27 \mathrm{p}$.

Brown, Eugene, Skougstad, M. W., and Fishman, M. J., 1970, Methods for collection and analysis of water samples for dissolved minerals and gases: U.S. Geological Survey Techniques of Water-Resources Investigations, bk. 5 , chap. A-1, $160 \mathrm{p}$.

Hem, J. D., 1970, Study and interpretation of the chemical characteristics of natural water, (2nd ed.): U.S. Geological Survey Water-Supply Paper $1473,363 \mathrm{p}$.

Norris, J. M., and Maura, W. S., 1985, Water-quality data for streams in the upper North Fork of the Gunnison River, Colorado: U.S. Geological Survey Open-File Report 85-190, $122 \mathrm{p}$.

Rushworth, Peter, Kelso, B. S., and Ladwig, L. R., 1984, Map, directory, and statistics of permitted Colorado coal mines, 1983: Colorado Geological Survey, Department of Natural Resources, map series 23.

Skougstad, M. W., Fishman, M. J., Friedman, L. C., Erdmann, D. E., and Duncan, S. S., 1979, Methods of analysis of water and fluvial sediments: U.S. Geological Survey Open-File Report 78-679, 1006 .

Tweto, Ogden, Steven, T. A., Hail, W. J., Jr., and Moench, R. H., 1976, Preliminary geologic map of the Montrose $1^{\circ} \times 2^{\circ}$ Quadrangle, Southeastern Colorado: U.S. Geological Survey Miscellaneous Field Studies Map MF-761, scale $1: 250,000$.

Tweto, Ogden, Moench, R. H., and Reed, J. C., Jr., 1978, Geologic map of the Leadville $1^{\circ} \times 2^{\circ}$ Quadrangle, Northwestern Colorado: U.S. Geological Survey Miscellaneous Investigation Series Map I-999, scale 1:250,000. 